\title{
Quantifying the effectiveness of climate change mitigation through forest plantations and carbon sequestration with an integrated land-use model Jelle G van Minnen¹, Bart J Strengers², Bas Eickhout², Rob J Swart² and Rik Leemans*1
}

\author{
Address: ${ }^{1}$ Environmental Systems Analysis Group, Wageningen University, P.O. Box 47, NL-6700 AA Wageningen, The Netherlands and \\ ${ }^{2}$ Netherlands Environmental Assessment Agency (MNP), P.O. Box 303, NL-3720 AH Bilthoven, The Netherlands \\ Email: Jelle G van Minnen - Jelle.van.minnen@mnp.nl; Bart J Strengers - Bart.strengers@mnp.nl; Bas Eickhout - Bas.eickhout@mnp.nl; \\ Rob J Swart - Rob.Swart@mnp.nl; Rik Leemans* - Rik.Leemans@wur.nl \\ * Corresponding author
}

Published: I5 April 2008

Carbon Balance and Management 2008, 3:3 doi:10.1186/1750-0680-3-3

This article is available from: http://www.cbmjournal.com/content/3/I/3

(C) 2008 van Minnen et al; licensee BioMed Central Ltd.

This is an Open Access article distributed under the terms of the Creative Commons Attribution License (http://creativecommons.org/licenses/by/2.0), which permits unrestricted use, distribution, and reproduction in any medium, provided the original work is properly cited.
Received: 20 December 2007

Accepted: 15 April 2008

\begin{abstract}
Background: Carbon plantations are introduced in climate change policy as an option to slow the build-up of atmospheric carbon dioxide $\left(\mathrm{CO}_{2}\right)$ concentrations. Here we present a methodology to evaluate the potential effectiveness of carbon plantations. The methodology explicitly considers future long-term land-use change around the world and all relevant carbon (C) fluxes, including all natural fluxes. Both issues have generally been ignored in earlier studies.
\end{abstract}

Results: Two different baseline scenarios up to 2100 indicate that uncertainties in future land-use change lead to a near $100 \%$ difference in estimates of carbon sequestration potentials. Moreover, social, economic and institutional barriers preventing carbon plantations in natural vegetation areas decrease the physical potential by $75-80 \%$ or more.

Nevertheless, carbon plantations can still considerably contribute to slowing the increase in the atmospheric $\mathrm{CO}_{2}$ concentration but only in the long term. The most conservative set of assumptions lowers the increase of the atmospheric $\mathrm{CO}_{2}$ concentration in 2100 by a 27 ppm and compensates for $5-7 \%$ of the total energy-related $\mathrm{CO}_{2}$ emissions. The net sequestration up to 2020 is limited, given the short-term increased need for agricultural land in most regions and the long period needed to compensate for emissions through the establishment of the plantations. The potential is highest in the tropics, despite projections that most of the agricultural expansion will be in these regions. Plantations in high latitudes as Northern Europe and Northern Russia should only be established if the objective to sequester carbon is combined with other activities.

Conclusion: Carbon sequestration in plantations can play an important role in mitigating the buildup of atmospheric $\mathrm{CO}_{2}$. The actual magnitude depends on natural and management factors, social barriers, and the time frame considered. In addition, there are a number of ancillary benefits for local communities and the environment. Carbon plantations are, however, particularly effective in the long term. Furthermore, plantations do not offer the ultimate solution towards stabilizing $\mathrm{CO}_{2}$ concentrations but should be part of a broader package of options with clear energy emission reduction measures. 


\section{Background}

Climate on earth is changing and this has led to a series of impacts on the environment and human society [1]. This climate change is most likely caused by the increased greenhouse gas concentration with carbon dioxide $\left(\mathrm{CO}_{2}\right)$ as the most important gas [2]. The United Nations Framework Convention on Climate Change (UNFCCC) in its mandate to limit future climate change and its impacts, aims to 'stabilize greenhouse gas (GHGs) concentrations in the atmosphere at a level that would prevent dangerous anthropogenic interference with the climate system' (Article 2 [3]). Many studies have compared emission reduction strategies to achieve different stabilization levels of $\mathrm{CO}_{2}$ and quantified their consequences (e.g. [4,5]). Most of these studies concentrate on reducing energy-related $\mathrm{CO}_{2}$ emissions and ignore abatement options that enhance $\mathrm{CO}_{2}$ uptake (or increase $\mathrm{C}$ sinks) by the biosphere. Such uptake also slows down the concentration increase.

The Kyoto Protocol, drafted in 1997 and entered into force in 2005, includes quantitative targets for industrial countries (the so-called "Annex B") to limit the emissions of six GHGs $\left(\mathrm{CO}_{2}, \mathrm{CH}_{4}, \mathrm{~N}_{2} \mathrm{O}\right.$, and three fluorinated gases) by the 2008-2012 period. In addition to reducing emissions from fossil fuel burning, the Kyoto Protocol provides explicit opportunities for Annex B countries to partly achieve their reduction commitments by planting new forests, or by managing existing forests or agricultural land differently (so-called Land-Use, Land-Use Change and Forestry measures: LULUCF). The presumption of these LULUCF options is that removing $\mathrm{CO}_{2}$ from the atmosphere can also contribute to the stabilization of the atmospheric $\mathrm{CO}_{2}$ concentration and thus to a limitation of climate change. After the Kyoto Protocol was signed, a number of technical issues regarding the use of carbon plantations in achieving the country commitments remained open. For example, it has been unclear how to quantify the LULUCF potential, both in the short and the long terms. Furthermore, criticism on establishing new forests (so-called carbon plantations) as a mitigation strategy were related to the permanency of sequestration and whether the sequestration is additional to default developments (e.g. [6]). Permanency is uncertain, since the pressure on land for other purposes than carbon plantations may increase considerably in the near future along with shifts in disturbance regimes. The Food and Agriculture Organization of the United Nations (FAO), for example, projects considerable increases in arable land needed for food production [7], whereas land requirements for modern biofuels are increasing considerably as well [8]. Furthermore, the Kyoto Protocol clearly states that activities should not be in conflict with existing conventions, such as the Convention on Biological Diversity. Thus land-use changes that drive losses in biodiversity should be prevented [9].

The Kyoto Protocol has resulted in several studies estimating the sequestration potential in plantations. The IPCC's special report on Land use, land-use change and forestry (LULUCF), for example, suggests that there is a potential to sequester an additional $87 \mathrm{Pg} \mathrm{C}$ by 2050 in global forests alone [10]. Other studies even suggest that land-based mitigation could be cost-effective compared to energyrelated mitigation options, and could provide a large proportion of the total mitigation $[11,12]$. However, it is often difficult to compare the results of these studies because they differ in terms and definitions and methods used. Furthermore, studies determine the sequestration potential in specific regions or specific land-cover types (e.g. [13-15]). Finally, there are studies that incorporate crude assumptions for future land-use change. For example, Sathaye et al. [16] based their projections of $\mathrm{C}$ sinks on linear extrapolation of continuing deforestation and afforestation rates, whereas Sohngen \& Sedjo [17] only considered an increase in forest product demand, discarding future food demand.

The main objective of this paper is to present a methodology that quantifies the possible role of $\mathrm{C}$ plantations around the world in mitigating the build-up of $\mathrm{CO}_{2}$ in the atmosphere at different cost levels and assumptions; it also takes into account the aforementioned limitations and concerns. We specifically address the issue of net carbon sequestration, including the continued carbon sequestration of the original natural vegetation. Moreover, we only consider the carbon sequestration potential in regions that are not used for other ecosystem services (like food supply), and include future land-use change. In this study we use the methodology as being implemented in the IMAGE-2 model (Integrated Model to Assess the Global Environment [18]) to show the long-term potential in eighteen different world regions.

\section{Results}

We present the global and regional distribution and $\mathrm{C}$ uptake potential of plantations for the different experiments and scenarios up to 2100 (see methodology section for detailed definitions of the different potentials). First, the physical potential is given (Experiments 1, 2 and 3), which is the potential based on local physical, ecological and environmental conditions. Second, the physical potential is translated into a social potential by taking interference with food and wood availability and nature conservation as main limitations (Experiments 4,5 and 6 ). This is a general attempt to simulate societal barriers to the establishment of plantations that can also include other, such as, for example, institutional factors. These factors differ between regions, and hence the uncertainty 
within our projected "social potential" may be larger than that within the physical potential. The final step 3 (= economic potential, including also land and establishment costs) is described in detail in Strengers et al [19], including the sequestration potential. The experiments differ with respect to the used management of the carbon plantations and baseline scenarios used. The latter refer to the IPCC SRES A1b and B2 baseline scenarios [20] (see section on Model application for differences between these scenarios). Regarding management, the carbon plantations are either harvested at regular intervals or not harvested at all (called permanent carbon plantation). These management options can have a considerable effect on the uptake potential of plantations (see methodology section).

\section{Experiments I, 2 and 3: Physical potential of carbon plantations}

In these experiments carbon plantations are established wherever they can grow and wherever they are carboneffective compared to the baseline. Under this assumption, the six plantation types are found to be effective over large areas around the world (Figure 1). Under the A1b baseline scenario, about 3990 and 3850 Mha (i.e. $10^{10}$ $\mathrm{m}^{2}$ ) plantations can be established under the permanent and frequent-harvest management options, respectively up to 2100 (Table 1). Plantations of gum species (Eucalyptus spp.), for example, are projected for establishment mainly in regions that are currently covered by savanna, woodland and even some tropical forest. The potential over the next few decades is limited because much land is needed for agricultural production (this land cannot be used because of the assumption that current and future agricultural land is to be excluded). Under the alternative B2 baseline scenario less land is projected to become available for plantations than under the A1b baseline, due to greater demand for agricultural land. The projected difference between the two management options (i.e. harvested or permanent plantations) has two reasons. First, the difference results from the assumption for permanent plantations that abandoned agricultural land is not avail- able if the re-grown natural forest is used at a later stage to fulfill the wood demand. Second, close to 2100 permanent plantations are estimated to be more widely distributed because the $\mathrm{CO}_{2}$ emissions related to the harvest of plantations need to be compensated before harvested plantations become an effective $\mathrm{C}$ sink.

The projected cumulative physical $\mathrm{C}$ sequestration of plantations in the A1b scenario is $583 \mathrm{Pg} \mathrm{C}$ and $913 \mathrm{Pg} \mathrm{C}$ up to 2100 for the permanent and harvest options, respectively (Figure 2). Under the $\mathrm{B} 2$ baseline scenario, the cumulative potential is estimated to be 858 Pg C, considering frequent harvests (i.e. $6 \%$ less compared to $\mathrm{A} 1 \mathrm{~b}$ ). These uptake rates equal about $37 \%$ and $58 \%$ of the projected overall $\mathrm{CO}_{2}$ energy and industry emissions in the A1b scenario for the permanent and harvest options, respectively. Under the $\mathrm{B} 2$ baseline, the estimated uptake is even $67 \%$ of the energy and industry emissions. Hence, the projected long-term physical potential of carbon plantations for slowing down the atmospheric $\mathrm{CO}_{2}$ increase is large. However, it will take more than 20 years to compensate for carbon emissions related to the establishment of the plantations. The projected physical potential up to 2020 is negligible where the cumulative potential up to 2030 is about $100-150 \mathrm{Pg} \mathrm{C}$ (Figure 2).

The two management options show a higher $\mathrm{C}$ sequestration potential in the case of harvested carbon plantations, especially beyond 2050 (Figure 2). This is caused by a decreasing sequestration rate for permanent carbon plantations, whereas the uptake potential remains high if a carbon plantation is frequently harvested harvests. This difference is induced by the $\mathrm{C}$ sequestration of plantations decreasing with age. The average age increases in permanent plantations but remains low in the frequent harvest case. This difference is projected specifically for plantations in Latin America and Africa.

Geographically speaking, the highest physical sequestration rates have been projected for plantations in tropical regions like South America and Africa, dominated by the

Table I: Physical potential distribution of carbon plantations (in Mha).

\begin{tabular}{|c|c|c|c|c|c|c|c|c|c|}
\hline Baseline & Alb Permanent & & & A Ib Harvest & & & B2 Harvest & & \\
\hline & 2030 & 2050 & 2100 & 2030 & 2050 & 2100 & 2030 & 2050 & 2100 \\
\hline River red gum & 545 & 620 & 965 & 621 & 700 & 997 & 514 & 533 & 701 \\
\hline Rose gum & 790 & 814 & 1310 & 1027 & 1039 & 1257 & 906 & 939 & 1157 \\
\hline Radiata pine & 20 & 25 & 33 & 20 & 25 & 33 & 22 & 30 & 38 \\
\hline Black poplar & 86 & $12 \mid$ & 445 & $|5|$ & 236 & 434 & 146 & 206 & 436 \\
\hline Norway spruce & 792 & 845 & 984 & 778 & 828 & 855 & 1047 & $|14|$ & 1254 \\
\hline Japanese larch & 100 & 158 & 254 & 128 & 183 & 272 & 139 & 195 & 247 \\
\hline Global total & 2333 & 2583 & 3992 & 2726 & 3011 & 3848 & 2774 & 3044 & 3833 \\
\hline
\end{tabular}



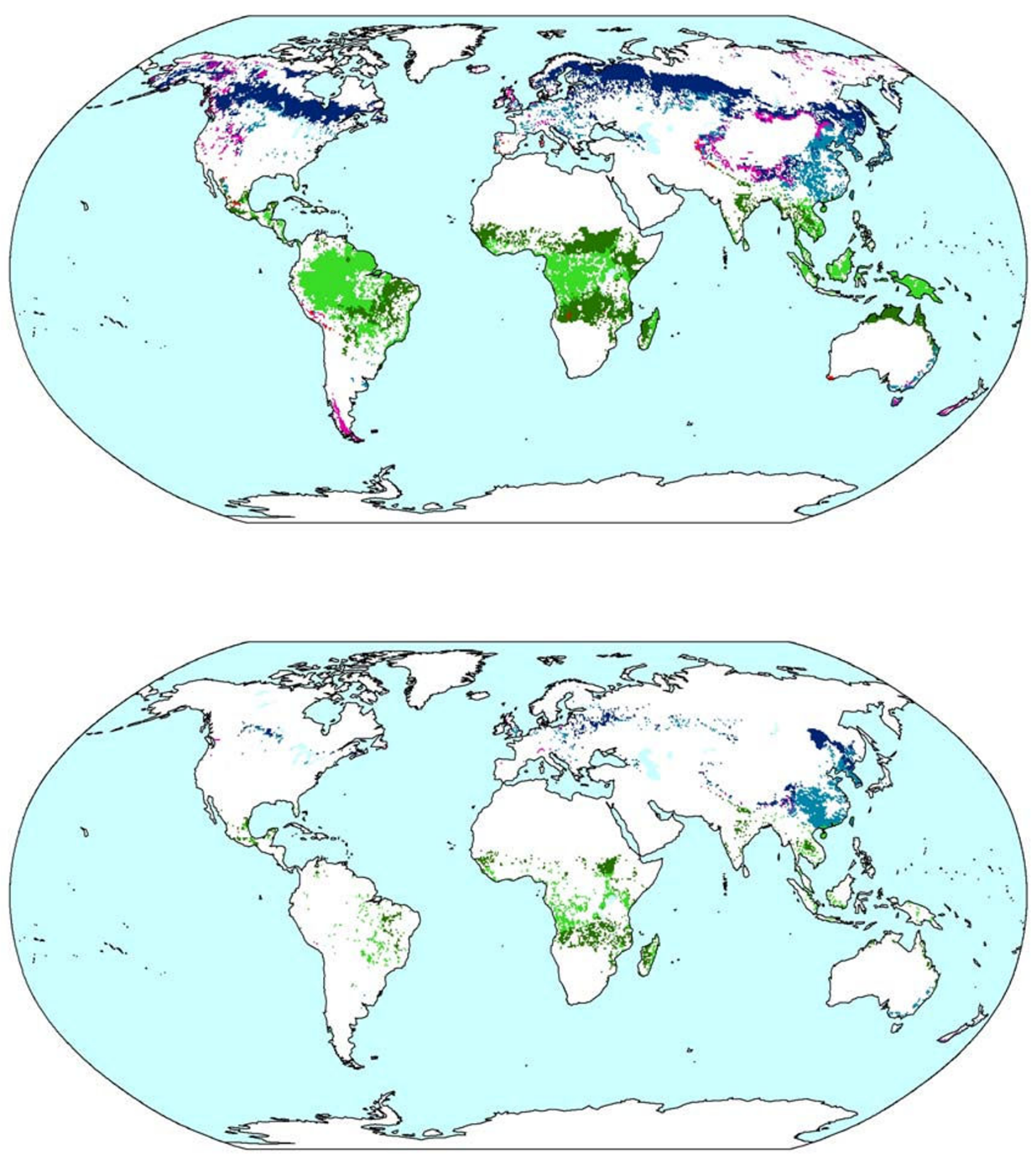

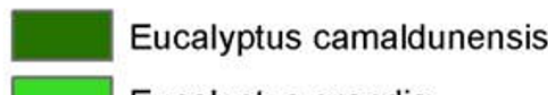

Eucalyptus grandis
Pinus radiata

Populus nigra
Picea abies

Larix Kaempferi

Figure I

Physical (top) and social (bottom) potential distribution of permanent carbon plantations in 2100 using the Alb scenario. 

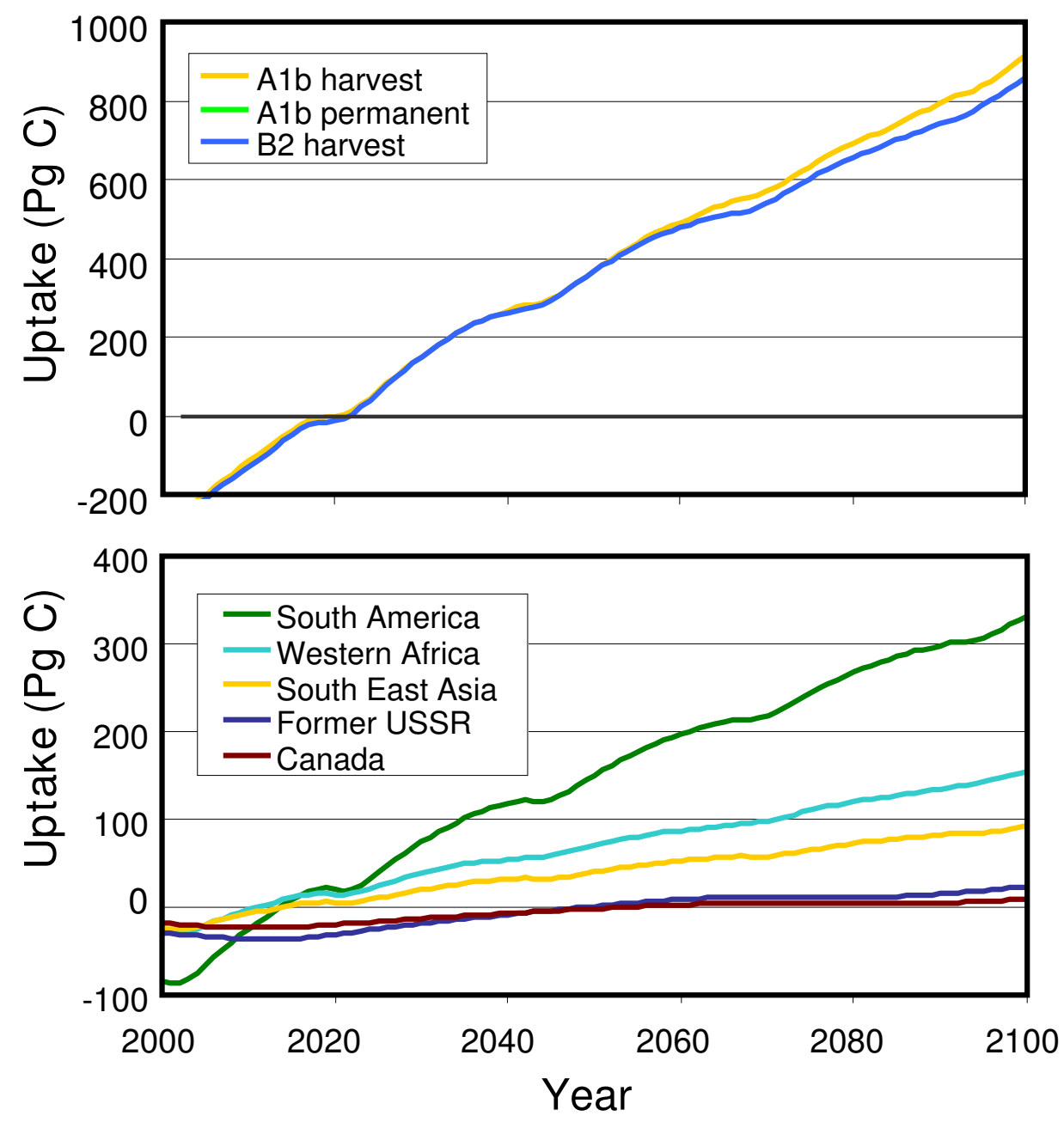

Figure 2

Cumulative physical global (top) and regional (bottom) $\mathbf{C}$ sequestration potential (CSeq). The regional figure illustrates the trend in the Alb harvest experiment (in $\mathrm{Pg} \mathrm{C}$ ).

two Eucalyptus plantation types (Figure 2). The projected sequestration potential is relatively low in high latitudes, because of low growth rates. In various parts of Canada and Russia, the net cumulative carbon sequestration even remains negative for about 50 years.

\section{Experiments 4, 5 and 6: Social potential of carbon plantations}

We assessed the social sequestration potential of $\mathrm{C}$ plantations up to 2100 using wood availability and nature conservation as main constraints in addition to the food security criterion. These constraints have been implemented by estimating the potential on abandoned agricultural land only. Assuming permanent carbon plantations (Experiment 4), 181 and 831 Ma are projected in the A1b scenario potentially to be established around the world up to 2050 and 2100, respectively (Table 2). In the case of harvested carbon plantations, the area available in 2100 is projected to be 1014 and 695 Mha under the $\mathrm{A} 1 \mathrm{~b}$ and $\mathrm{B} 2$ baseline scenarios, respectively (Experiments $5 \& 6$ ). The difference between the baseline scenarios is caused by a larger land abandonment under the A1b baseline scenario than under the $\mathrm{B} 2$ baseline. The difference between the two management options is caused by the assumption for permanent carbon plantations that abandoned agricultural land is not available if the regrown natural forest is needed at a later stage to fulfill the wood demand. For frequently harvested carbon plantations, the timber from the plantations is used to fulfill the wood demand, reducing the pressure on existing forests. Similar to the physical potential, the difference between the management options is projected to decrease near to 2100 because the $\mathrm{CO}_{2}$ emissions related to the harvest need to be compensated before the plantations become 
Table 2: Social potential distribution of carbon plantations with establishment on abandoned agricultural land only (in Mha).

\begin{tabular}{|c|c|c|c|c|c|c|c|c|c|}
\hline Baseline & Alb Permanent & & & Alb Harvest & & & B2 Harvest & & \\
\hline & 2030 & 2050 & 2100 & 2030 & 2050 & 2100 & 2030 & 2050 & 2100 \\
\hline River red gum & 31 & 75 & 317 & 33 & 83 & 332 & 30 & 37 & 158 \\
\hline Rose gum & 20 & 26 & 230 & 30 & 41 & 256 & 21 & 34 & 108 \\
\hline Radiata pine & 2 & 2 & 3 & 2 & 2 & 3 & 2 & 2 & 3 \\
\hline Black poplar & 16 & 24 & 192 & 23 & 83 & 219 & 31 & 84 & 163 \\
\hline Norway spruce & 31 & 48 & 75 & 128 & 164 & 181 & 119 & 203 & 234 \\
\hline Japanese larch & 4 & 5 & 14 & 11 & 16 & 22 & 15 & 23 & 29 \\
\hline Global total & 105 & 181 & 831 & 228 & 390 & 1014 & 218 & 383 & 695 \\
\hline Canada & 2.2 & 6.7 & 14.8 & 16.2 & 27.2 & 26.4 & 15.9 & 36.2 & 30.2 \\
\hline US & 0.9 & 0.9 & 2.9 & 5.0 & 5.2 & 5.1 & 18.4 & 53.2 & 69.0 \\
\hline Europe & 0.3 & 0.9 & 19.5 & 4.3 & 12.2 & 24.7 & 17.4 & 36.5 & 35.4 \\
\hline FSU & 13.7 & 20.5 & 49.9 & 48.7 & 67.1 & 79.9 & 80.6 & 107.1 & 135.8 \\
\hline China & 0.3 & 14.9 & 187.5 & 3.0 & 60.8 & 254.7 & 0.0 & 25.2 & 125.2 \\
\hline Latin America & 40.0 & 47.7 & 102.9 & 76.3 & 85.9 & 133.3 & 35.5 & 56.6 & 63.8 \\
\hline Africa & 6.4 & 43.5 & 314.6 & 10.5 & 61.1 & 326.1 & 0.4 & 1.6 & 124.8 \\
\hline India & 0.4 & 0.4 & 54.8 & 0.6 & 0.6 & 56.5 & 1.2 & 1.2 & 27.2 \\
\hline SE-Asia & 0.0 & 0.0 & 27.6 & 0.0 & 0.9 & 30.4 & 0.0 & 0.0 & 7.2 \\
\hline Oceania & 41.0 & 45.7 & 53.8 & 63.5 & 69.0 & 74.5 & 47.7 & 65.5 & 71.5 \\
\hline
\end{tabular}

an effective $\mathrm{C}$ sink. As a consequence, fewer harvested plantations will be established.

The majority of the carbon plantations is projected in all the experiments to be established after 2050, because land only becomes available then, due to decreasing population and increasing efficiency. The projected cumulative global social $\mathrm{C}$ sequestration potential remains low in the coming decades (Figure 3), and, up to 2050, reaches 12-17 Pg C for the different baselines and harvest regimes (Table 3). Under the A1b scenario the potential increases up to 93 and $133 \mathrm{Pg} \mathrm{C}$ in 2100 for permanent and harvested plantations, respectively (Figure 3 and Table 3). This is $5-7 \%$ of the projected cumulative emissions up to 2100 coming from the energy and industry sector (i.e. about $1740 \mathrm{Pg} \mathrm{C}$ ). The potential uptake up to 2100 under the B2 scenario is $68 \mathrm{Pg} \mathrm{C}$, implying $5 \%$ of the energy and industry emissions (i.e. $1272 \mathrm{Pg} \mathrm{C}$ ). The net $\mathrm{C}$ sequestration potential can be higher under a frequent harvest regime due to a higher area-based uptake and the broader distribution. Comparing the 2 baseline scenarios, the projected global sequestration of carbon plantations in 2100

Table 3: Implications of establishing carbon plantations on abandoned agricultural land.

\begin{tabular}{|c|c|c|c|c|c|c|}
\hline \multirow[t]{2}{*}{ Indicator } & \multicolumn{3}{|l|}{2050} & \multicolumn{3}{|l|}{2100} \\
\hline & Alb perm. & Alb harvest & B2 harvest & Alb perm. & Alb harvest & B2 harvest \\
\hline Baseline atmos. $\mathrm{CO}_{2}$ concentration (ppm) & 561 & 561 & 506 & 753 & 753 & 606 \\
\hline Change in $\mathrm{CO}_{2}$ concentration, compared to baseline (ppm) & -5 & -6 & -8 & -39 & -52 & -27 \\
\hline \multicolumn{7}{|l|}{$\begin{array}{l}\text { Cumulative social } \mathrm{C} \text { sequestration potential in } \mathrm{C} \text { plantations on } \\
\text { abandoned agricultural land only }(\mathrm{Pg} \mathrm{C})\end{array}$} \\
\hline Global potential & 12 & 17 & 17 & 93 & 133 & 68 \\
\hline Canada & 0.2 & 0.6 & 0.8 & 0.7 & 1.7 & 1.9 \\
\hline US & 0.1 & 0.3 & 1.7 & 0.3 & 0.6 & 7.5 \\
\hline Europe & 0.1 & 0.4 & 1.5 & 0.7 & 2.3 & 3.6 \\
\hline FSU & 0.6 & 1.9 & 3.9 & 3.4 & 5.2 & 7.7 \\
\hline China & 0.1 & 0.8 & 0.2 & 10.3 & 26.3 & 10.3 \\
\hline Latin America & 4.2 & 5.0 & 3.8 & 13.6 & 18.2 & 13.0 \\
\hline Africa & 2.8 & 3.5 & 0.1 & 47.9 & 57.6 & 8.1 \\
\hline India & 0.0 & 0.0 & 0.2 & 6.5 & 6.8 & 2.9 \\
\hline SE-Asia & 0.0 & 0.0 & 0.0 & 0.2 & 2.8 & 0.7 \\
\hline Oceania & 4.0 & 4.4 & 5.1 & 9.8 & 11.2 & 12.3 \\
\hline
\end{tabular}



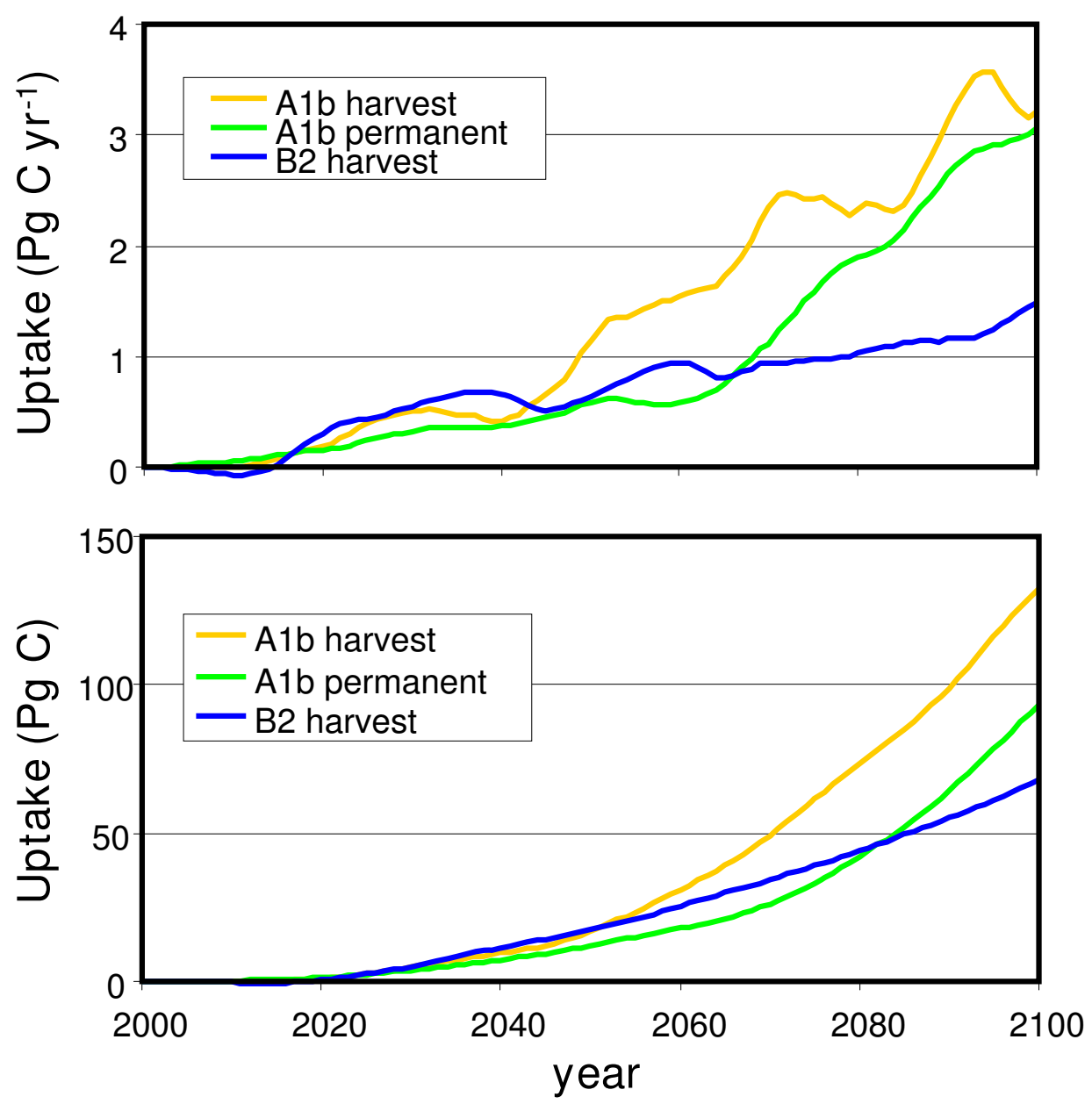

Figure 3

Social C sequestration potential (CSeq) on abandoned agricultural land; top - annual (Pg C/yr), bottom - cumulative $(\mathrm{Pg} \mathrm{C})$.

is $95 \%$ higher under the A1b scenario than in the B2 baseline (Table 3 ). This is mainly due to the higher establishment rates.

Geographically speaking, most plantations are projected for establishment in tropical regions (Figure 1 and Table 2 ). The consequences for the $\mathrm{C}$ sequestration are that under the A1b baseline scenario, $40-50 \%$ of the global potential can be sequestered in plantations in Africa, 10-20\%, in China, $10 \%$ in Latin America, and 10\% in Oceania (Table 3). Although a considerable amount of abandoned agricultural land is projected for Europe, Canada and the FSU as well, the effectiveness of establishing $\mathrm{C}$ plantations here is projected as being rather limited. For example, $6 \%$ of the global potential area can be established in the FSU up to 2100 , sequestering only $4 \%$ of the global potential.
With respect to the social potential, evaluating the effectiveness of carbon plantations in slowing down the buildup of $\mathrm{CO}_{2}$ in the atmosphere shows that the concentration in 2100 under the A1b scenario can be reduced from 752 to 713 ppm (i.e. a 39 ppm reduction) when planting permanent carbon plantations, whereas it reaches 700 ppm (i.e. a 52 ppm reduction) assuming frequently harvested plantations (Table 3). The two management options differ because of the broader distribution of carbon plantations when planting frequently harvested plantations and because of the additional $\mathrm{C}$ that will be stored in the soil compartment. The lower social sequestration potential projected under the $\mathrm{B} 2$ baseline scenario results, obviously, in a lower effectiveness. Assuming frequently harvested carbon plantations, we project a $\mathrm{CO}_{2}$ concentration of 579 ppm in 2100, which is 27 ppm less than in the baseline. 


\section{Discussion \\ The carbon sequestration potential in comparison with other studies}

Here we have presented a methodology to assess the global and regional sequestering potential of carbon plantations established after 2000. Based on ecological and environmental constraints alone, carbon plantations can be effective in large parts of the world with a projected cumulative sequestering potential of $913 \mathrm{Pg} \mathrm{C}$ up to 2100. In the A1b baseline scenario this equals $52 \%$ of the total cumulative $\mathrm{CO}_{2}$ emissions from energy and industry from 2000 to 2100 . In the B2 scenarios it is even $67 \%$. The social sequestration potential is much lower but still considerable. The annual average global potential is projected at $0.1-0.2 \mathrm{Pg} \mathrm{C} \mathrm{yr}^{-1}$ up to 2050, and 0.68-1.3 $\mathrm{Pg} \mathrm{C} \mathrm{yr}^{-1} \mathrm{up}$ to 2100 (Table 3). In 2100 this leads to a 27-52 ppm smaller increase in the atmospheric $\mathrm{CO}_{2}$ concentration and compensates for $5-7 \%$ of the total energy and industry related $\mathrm{CO}_{2}$ emissions. The sequestration potential is likely to considerably increase beyond 2100, because many plantations are projected to be established only close to the end of the $21^{\text {st }}$ century. This holds especially for regions where large areas of arable land are expected to be abandoned towards 2100, such as China.

The social sequestration potential of the plantations projected up to 2050 is at the low end of ranges found in the literature, whereas values for the coming 100 years are more in line (Table 4). Geographically, the most effective plantations are located in tropical regions, whereas due to low growth rates the $\mathrm{C}$ sequestration in high latitudinal plantations is limited (Table 3 ). This is in line with the findings of Masera et al. [21] and Cannell [22]. Many other estimates are especially useful in a comparison with our area-based potentials, because the studies often focus on the $\mathrm{C}$ sequestration potential in existing forests (Table $4)$. For example, the projected social C sequestration potential of tropical plantations of Latin America and Africa (1.6-1.9 Mg C ha-1 $\mathrm{yr}^{-1}$ for 2000-2100), is found at the low end of the range given by Silver et al. [23]. Our projections for Europe up to 2100 - between 0.3 and 1.1 $\mathrm{Mg} \mathrm{C}$ ha-1 yr-1 - are well in line with the projected areabased uptake of $0.52 \mathrm{Mg} \mathrm{C}$ ha- 1 yr- 1 given by Liski et al [24]. Note that we have used a particular definition of "social potential", possibly causing differences with other studies in either direction. Areas that we excluded, for example, because of competition with other needs may be converted in reality, while areas that we included could not be appropriate for the establishment of plantations because of other social or institutional factors.

Despite the estimated considerable $\mathrm{C}$ sequestration potential up to 2100, the uptake potential for the coming decades is projected to be limited (Figure 3). It can take about 20 years to compensate for the emissions related to the establishment of the plantations. Moreover, not much agricultural land will likely be abandoned in coming decades due to the current and projected agricultural pressure. The limited potential in coming decades is in line with findings of Marland \& Schlamadinger [25], who showed that the sequestration potential in forests established since 1990 is mainly relevant in the long term. As such, we do not confirm the suggestion of Kirschbaum [26] that plantations may help to buy some time in initiating emission reductions already in the next few decades.

The limited role of plantations in the coming decades might be caused by our assumptions that $\mathrm{C}$ plantations can only be established after 2000. Various other studies report afforestation activities in different locations around the world, even before 2000. Brown [27] and FAO [28], for example, reported that globally $124 \mathrm{Mha}$ and $187 \mathrm{Mha}$ forest plantations have been established up to 1995 and 2000, respectively. More than 90\% of these plantations have been established in 30 countries only, mainly in such Asian countries as China (45 Mha), India (32 Mha), and Japan (11 Mha). Furthermore, various studies report existing afforestation activities, but seldom account for deforestation in the same region (the so-called leakage effect). This has also been shown by others (e.g. [29]) by estimating an annual afforestation rate in the tropics of 2.6 $\mathrm{Mha} \mathrm{yr}^{-1}$ throughout the $1980 \mathrm{~s}$, but at the same time a

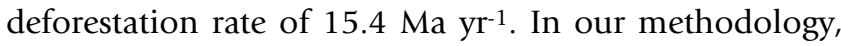
leakage is not possible because we only establish plantations on land that is available for the entire simulation period (i.e. up to 2100). Finally, our projections are lower than in other studies that account for the $\mathrm{C}$ sequestration in forests planted for various other reasons (e.g. recreation, agroforestry and soil restoration). For India, for example, we have project a negligible afforestation potential up to 2030 because of the large pressure on the land for food production. Nevertheless, Ravindranath \& Somashekhar [30] reported an afforestation rate of India of 1.6 Mha $\mathrm{yr}^{-1}$, mainly for agroforestry purposes. Again, these afforestation rates are partly counterbalanced by deforestation activities in India [30,31].

\section{The methodology in relation to conventions and protocols} The methodology presented is aimed at quantifying the sequestration potential of carbon plantations around the world, in consideration of the requirements mentioned in different conventions and protocols. The UN Framework Convention on Climate Change [3] and its underlying Kyoto Protocol, which opened the possibility for developed countries to use afforestation programs in achieving their reduction commitments, clearly stress that $\mathrm{C}$ plantations are only effective in the long term if (see also $[10,32,33])$ :

- they are additional to a baseline; 
Table 4: Comparison of existing $C$ sequestration projections.

\begin{tabular}{|c|c|c|c|c|}
\hline Reference & $\begin{array}{l}\text { Total C sequestra- } \\
\text { tion }\left(\mathbf{P g} \mathrm{Cyr}^{-1}\right)\end{array}$ & $\begin{array}{c}\text { Areal C sequestration } \\
\left(\mathrm{MgC} \mathrm{ha}^{-1} \mathrm{yr}^{-1}\right)\end{array}$ & Period & Remarks \\
\hline \multicolumn{5}{|l|}{ Global studies } \\
\hline $\begin{array}{l}\text { This study (social } \\
\text { potential) }\end{array}$ & $0.12-0.170 .68-1.33$ & $0.9-1.30 .8-1.3$ & $2000-20502000-2100$ & $\begin{array}{l}\text { Considering sequestration on abandoned } \\
\text { agricultural land only }\end{array}$ \\
\hline$[10]$ & $0.2-0.58$ & & $2008-2012$ & \\
\hline$[22]$ & $0.2-1$ & & $2000-2050$ & Conservative potential for 50 -year period \\
\hline$[55]$ & $0.3-2.9$ & $0.8-1.6$ & $2000-2075$ & $\begin{array}{l}\text { Large variation due to different assumptions } \\
\text { on yields }\end{array}$ \\
\hline [61] & avg 1.04 & & $1995-2095$ & \\
\hline [62] & $0.15-0.8$ & & $2008-2012$ & \\
\hline [63] & $0.6-1.2$ & & $2000-2050$ & $\begin{array}{l}\text { Only in degraded land soils. Total potential is } \\
30-60 \mathrm{Pg} \mathrm{C} \text {. }\end{array}$ \\
\hline \multicolumn{5}{|c|}{ Regional studies (Compared to Table 3) } \\
\hline [22] & $0.02-0.05$ & & & Europe, a 100 -year period \\
\hline [23] & & $2-3.5$ & & $\begin{array}{l}\text { Average sequestration of tropical forests } \\
\text { during an } 80 \text {-year period }\end{array}$ \\
\hline \multirow[t]{5}{*}{ [55] } & & & & $\begin{array}{l}\text { Only above-ground sequestration. soil } \\
\text { decomposition fluxes excluded }\end{array}$ \\
\hline & & $0.6-1$ & & Canada \\
\hline & & $0.5-11$ & & USA (many studies summarized) \\
\hline & & $1.4-2.3$ & & Western Europe \\
\hline & & 7.5-7.7 & & Australia \\
\hline \multirow[t]{3}{*}[64]{} & 0.006 & & 2010 & EU25 countries \\
\hline & 0.01 & & 2020 & \\
\hline & 0.02 & & 2030 & \\
\hline [65] & 0.050 .12 & & 2100 & $\begin{array}{l}\text { EUI5. only soils Wider Europe (excl. Russia). } \\
\text { only soils }\end{array}$ \\
\hline [66] & & $0.3-0.6$ & & European forests during $2008-2012$ \\
\hline [67] & & 0.35 & & North-west Russia \\
\hline [68] & & 1.4 & 1999-2000 & Canada \\
\hline \multirow[t]{5}{*}{ [69] } & 0.88 & 0.3 & Current & Sink of all boreal and temperate forests \\
\hline & 0.11 & 0.52 & & All European forests \\
\hline & 0.43 & 0.48 & & All Russian forests \\
\hline & 0.10 & 0.25 & & All Canadian forests \\
\hline & 0.17 & 0.56 & & All US forests \\
\hline
\end{tabular}

- all C fluxes are considered (i.e. full C accounting);

- they are permanent. If not, a carbon plantation has little value in terms of actually reducing the concentration of GHG in the atmosphere, since carbon sequestered over various years will return to the atmosphere;

- the credited $\mathrm{C}$ sequestration in one region is not to be compensated by C losses elsewhere (i.e. no leakage [34]),

- the $\mathrm{C}$ sequestration in plantations exclude 'indirect human influences' in terms of, for example, climate and $\mathrm{CO}_{2}$ change.

The additionality issue has been taken into account in the methodology presented by considering the sequestration potential of both plantations and natural ecosystems. Furthermore, the methodology considers all $C$ fluxes by keeping track of fluxes in both vegetation and soil, plus the carbon losses due to the establishment of the plantations. The permanency concern is taken into account by comparing the C plantation option with various other land-use options. Alternative land-use options pose a main threat to the permanency of a carbon plantation, especially in the long term (e.g. when the demand for agricultural land fluctuates or prices of land-use products change). Since permanency is more certain if plantations are established in areas that are not used for food, fodder and timber production, areas needed for agriculture or wood up to 2100 have been excluded in the all experiments. As mentioned earlier, leakage is not possible in the methodology presented because we only establish plantations on land 
available for the entire simulation period (i.e. up to 2100). Finally, the methodology accounts only for carbon sequestered directly by the plantations, corrected for climate change and $\mathrm{CO}_{2}$ fertilization (i.e. indirect human influences). This has been done both for the historical uptake - where we corrected 1995 growth rates for observed changes in $\mathrm{CO}_{2}$ and climate (see Equation 2) as well as the projected future (reducing the projected social potential in the supply curves for climate and $\mathrm{CO}_{2}$ changes in the baseline).

\section{The effectiveness of carbon plantations in a broader environmental context}

The effectiveness of harvesting plantations and using the biomass to displace fossil fuels and/or timber, compared to having carbon stored in a permanent plantation, depends to a great extent on the displacement factor (i.e. the extent to which wood from carbon plantations can be effectively used to replace fossil fuels) [35]. Here, a displacement factor of 'one' is assumed. Theoretically this can be achieved if fossil fuels are displaced by harvested wood [22,36]. However, if the displacement factor is (much) smaller than 'one', the environmental effectiveness of harvested plantations decreases sharply. Likewise, establishing carbon plantations is, in general, less effective than avoiding deforestation (especially in tropical regions, $[37,16])$. This, however, is associated with various social difficulties and avoiding deforestation in one region may be counterbalanced by additional deforestation elsewhere.

The effectiveness of carbon plantations in especially high latitudes is questioned because of the effect on different biophysical processes (i.e. changed radiation balance) that may counterbalance the additional $\mathrm{C}$ sequestration [38-40]. On the basis of the albedo effect and the projected low net sequestration potential for high latitudinal plantations (i.e. in parts of Canada and Russia the net $\mathrm{C}$ sequestration even remains negative for about 50 years), the establishment of carbon plantations in high latitudes is only favorable if the objective to sequester carbon is combined with other environmental considerations. For example, plantations may also contribute to water protection and soil erosion control [21,41].

An environmental constraint often mentioned for largescale $\mathrm{C}$ plantations is the availability of water and nitrogen [41-43]. Also in the methodology presented, the high growth rates of the carbon plantations (compared to natural forests) rely on a high level of management, including nitrogen fertilization for plantations situated on poor or degraded soils. The additional use of water and fertilizer should indeed be a concern in the planning and management of the plantation, especially because a (higher) fertilizer use could imply additional emissions of
$\mathrm{N}_{2} \mathrm{O}$, which were neither accounted for in our study, nor in most other studies. Likewise, afforestation activities have recently also been questioned in the context of possible additional methane emissions from trees - the second-most important greenhouse gas [44]. Although this issue is currently still under scientific debate, the effectiveness of afforestation programs would be reduced by a maximum of $10 \%$. This has been confirmed by others (see, for example, [45] for a more detailed discussion).

\section{Conclusion}

We have presented a rule-based methodology to quantify the long-term physical and social sequestration potential of carbon plantations up to the end of the $21^{\text {st }}$ century and their effectiveness in slowing down the increase in atmospheric $\mathrm{CO}_{2}$. Applying the methodology, we conclude that projected potentials differ considerably for different experiments, regions and management options. For example, we projected a nearly $100 \%$ difference in the sequestration potential up to 2100 between two baseline scenarios, showing the effect of uncertainties in future land use. Nevertheless, in all cases the $\mathrm{C}$ sequestration potential can be substantial. Even under a conservative set of assumptions, the cumulative sequestration potential up to 2100 compensates for $5-7 \%$ of the total energy and industry related $\mathrm{CO}_{2}$ emissions. But the sequestration potential is substantial only in the long term. The potential for the coming decades is limited due to the limited amount of available land and the long period needed to compensate for emissions related to the establishment of the plantations. Geographically speaking, plantations in tropical regions are most effective. The $\mathrm{C}$ sequestration potential of plantations in high latitudes is low and because of biophysical feedbacks on the climate system its effectiveness can even be questioned. The establishment of plantations in these regions is only favorable if the objective to sequester carbon is combined with other environmental considerations.

Finally, our analysis showed that $\mathrm{C}$ sequestration in plantations may be substantial and thus can help to slow down the future increase in atmospheric $\mathrm{CO}_{2}$. But $\mathrm{C}$ plantations do not represent the ultimate solution to the problem of establishing a stabilization of the atmospheric $\mathrm{CO}_{2}$ concentration. They should form part of a broader package of options, with clear measures for also reducing energy emissions.

\section{Methodology \\ The algorithm}

The methodology to assess the $\mathrm{C}$ sequestration potential in carbon plantations, as presented here, is a rule-based approach that is implemented on a geographical explicit $0.5^{\circ}$ longitude $\times 0.5^{\circ}$ latitude-grid (Figure 4). The time horizon is $2000-2100$. This facilitates the quantification 


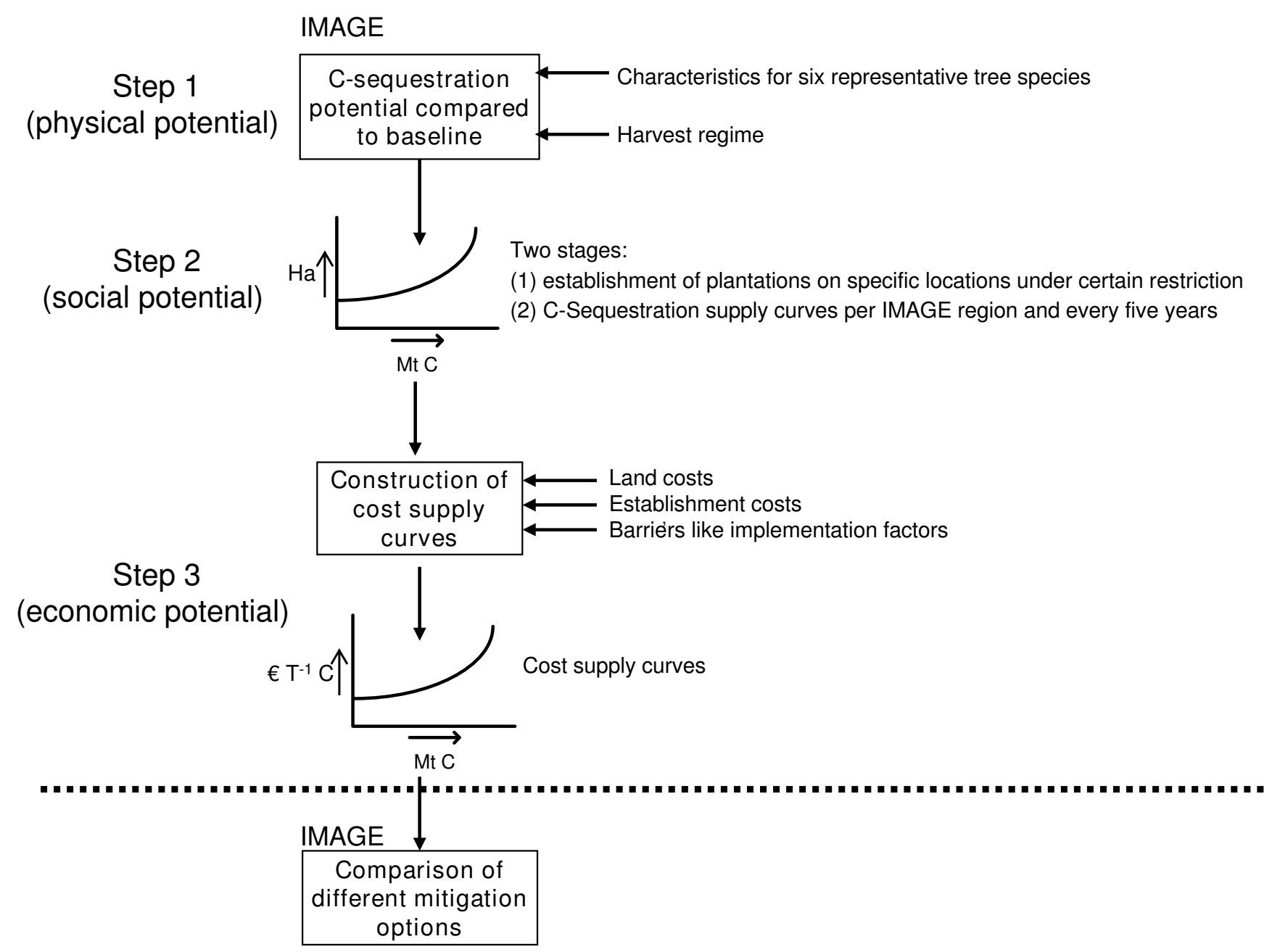

Figure 4

Steps to quantify sequestration potential of carbon plantations.

of the long-term potential of carbon plantations in different parts of the world in mitigating the build-up of $\mathrm{CO}_{2}$ in the atmosphere. We distinguish different potentials, defined according IPCC definitions [46]. The methodology consists of three steps (Figure 4). The first step is to determine the physical sequestration potential of $\mathrm{C}$ plantations, accomplish by adding carbon plantations as a new land cover class in IMAGE 2 (see below for a general description of the IMAGE 2 model). All carbon pools and fluxes of the potential carbon plantations (e.g. Net Primary Production - NPP and Net Ecosystem Productivity NEP) are calculated by the IMAGE- 2 terrestrial C-cycle model, taking environmental (e.g. climate and atmospheric $\mathrm{CO}_{2}$ ) and local conditions (e.g. soil) into consideration. In the second step, the social potential of plantations is determined using the restriction 'no interference with food supply and nature conservation'. In the third step, the social potential is transferred into the economic potential by linking the $\mathrm{C}$ sequestration potential to establishment and land costs. The resulting marginal abatement cost curves can be used to compare the potential of carbon plantations with other mitigation strategies using cost minimization (e.g. [47]). The focus of this paper is on describing and analyzing steps 1 and 2 of the methodology. We will also summarize step 3 (i.e. economic potential), but refer for details on this to the companion paper by Strengers et al. [19].

Step I: The physical sequestration potential

The starting point for this step is the potential distribution of $\mathrm{C}$ plantations around the world. Six plantations types were selected on the basis of the 'Top 14 Most Planted World's Trees' $[28,48]$ to represent suitable species in different climatic zones around the world (Table 5). We used, for example, gum species (Eucalyptus spp.) for the tropical regions, and spruce (Picea abies) and larch (Larix 
Table 5: The climatic characteristics of the selected tree species for carbon plantations.

\begin{tabular}{|c|c|c|c|c|c|c|}
\hline No & Tree species & & Corresponding PFT & $\mathrm{T}_{\text {cold }}\left({ }^{\circ} \mathrm{C}\right)$ & Moisture $^{2}$ & GDD5 $_{\text {min }}$ \\
\hline 1 & Eucalyptus camadulensis & River red gum & Tropical deciduous trees & $>15.5$ & 0.45 to 0.8 & \\
\hline 2 & Eucalyptus grandis & Rose gum & Tropical evergreen trees & $>15.5$ & 0.8 to 1.0 & \\
\hline 3 & Pinus radiate & Radiata pine & Temperate evergreen trees & $>5$ & 0.55 to 0.95 & \\
\hline 4 & Populus nigra & Black poplar & Temperate deciduous trees & -15 to 15.5 & 0.65 to 1.0 & 1200 \\
\hline 5 & Picea abies & Norway spruce & Boreal evergreen trees & -35 to -2 & 0.75 to 1.0 & 350 \\
\hline 6 & Larix kaempferi & Japanese Larch & Boreal deciduous trees & $<5$ & 0.65 to 1.0 & 350 \\
\hline
\end{tabular}

I $\mathrm{T}_{\text {cold }}$ is the average temperature of the coldest month.

2 Moisture is expressed as the ratio between actual and potential evapotranspiration [70]. The lower end of the range may decrease due to increasing Water Use Efficiency. This is the result of increasing atmospheric $\mathrm{CO}_{2}$ levels.

${ }^{3} \mathrm{GDD}_{\min }$ is the minimum degree-day sum for establishment (considering a $5^{\circ} \mathrm{C}$ base).

kaempferi) for plantations in cool and boreal regions, respectively. 'Potential distribution' in this context refers to the availability and suitability of land. Land is assumed to be available when it is not assigned as protected area and no longer used for agriculture (neither cropland nor pasture). Hence, a more realistic potential is provided, given the many other land-use purposes that may expand in the (short-term) future. Suitability of land is driven by various environmental conditions in terms of climate and soil. All these conditions need to be fulfilled to allow a specific plantation type in a certain region. The climatic characteristics of the plantations are derived from the best matching Plant Functional Types (PFT) - classes of plant species grouped according to physiological characteristics and the sensitivity to changes in temperature and water availability (Table 5).

Secondly, the best growing plantations out of these six types are determined for each grid cell by using the parameters describing the $\mathrm{C}$ dynamics (e.g. lifetimes, allocation fractions). These parameters of the different plantation types are linked to the parameters used for the natural land-cover type that best matches the plantation type considered (Tables 5 \&6; $[49,19])$. The Net Primary Produc- tion $\left(\mathrm{NPPCP}_{\mathrm{ts}}\right)$ rates averaged over the longest likely rotation length (LRL) of each plantation type (Equation 1) are compared. The longest LRL has been chosen to take into account the period needed to reach the maximum NPP for all possible plantation types.

$$
N P P C P_{t s}(t)=R F(t) \cdot F N P P_{l c t(t s)}(t) \cdot A G F_{t s}
$$

where

ts Index for tree species in a carbon plantation $(1, . ., 6)$

lct(ts) Land cover type by which the carbon dynamics of tree species (ts) are described (Table 1)

$\mathrm{RF}(\mathrm{t})$ Reduction Factor $(\leq 1)$ during the period towards maximum average growth in terms of NPP, i.e. the recovery time (-) (Table 1)

$\mathrm{FNPP}_{\text {lct(ts) }}(\mathrm{t})$ NPP of full-grown natural vegetation in year $\mathrm{t}$ if the grid cell were to be covered by land-cover type lct(ts), as computed by the IMAGE $2 \mathrm{C}$ cycle model (Mg C ha-1 yr-1)

Table 6: The carbon characteristics of the selected tree species for carbon plantations.

\begin{tabular}{|c|c|c|c|c|c|c|c|c|c|}
\hline No. & $\begin{array}{l}\text { Corresponding land } \\
\text { cover types }\end{array}$ & Yield ( $m^{3} /$ ha yr) & Recov. (yr) & LRL' (yr) & $\mathrm{HI}^{2}(-)$ & $W D^{3}\left(M g D M / m^{3}\right)$ & $\begin{array}{l}\mathrm{FNPP}_{\mathrm{CP}}(\mathrm{Mg} \mathrm{C} / \mathrm{ha} \\
\mathrm{yr})\end{array}$ & AGF (-) & CF95 $_{\text {ts }}$ (Eq. 2) \\
\hline I & $\begin{array}{l}\text { Trop. deciduous } \\
\text { forest }\end{array}$ & $12(3-20)$ & 8 & 15 & 0.65 & 0.550 & 18.9 & 2.02 & 1.041 \\
\hline 2 & $\begin{array}{l}\text { Trop. evergreen } \\
\text { forest }\end{array}$ & $20(10-35)$ & 8 & 15 & 0.70 & 0.425 & 22.2 & 1.77 & 1.042 \\
\hline 3 & Warm mixed forest & $14(10-30)$ & 15 & 28 & 0.87 & 0.450 & 11.0 & 1.62 & 1.045 \\
\hline 4 & $\begin{array}{l}\text { Temp. deciduous } \\
\text { forest }\end{array}$ & $16(8-28)$ & 18 & 25 & 0.83 & 0.350 & 11.8 & 1.77 & 1.022 \\
\hline 5 & Cool mixed forest & II (4-20) & 30 & 60 & 0.87 & 0.400 & 8.2 & 1.49 & 1.00 \\
\hline 6 & Boreal forest & $7(4-12)$ & 25 & 60 & 0.87 & 0.490 & 5.6 & 1.11 & 1.00 \\
\hline
\end{tabular}

I Likely Rotation Length: derived from [28] for both eucalyptus plantations; pine average of [48; 6I; 7I]; poplar based on [48; 7I]; spruce based on $[61]$ and larch derived from yield tables (e.g. [72; 73]), use the moment that growth rates start to decline.

2 Harvest Index-based [34]

3 Wood density mainly based on [34]; If not available, use [7।; 74; 75; 76]. 
AGF $_{\mathrm{ts}}$ Additional Growth Factor of tree species ts (-), (Table 1, Equation 2)

The additional growth factor $\left(A G F_{t s^{\prime}}\right.$ Equation 2) is defined as the growth rate of a plantation - based on a literature review (Equation 3) - compared to the average growth of the natural land-cover type, corrected for historical environmental changes - $C F 95_{t s}$. The latter correction factor is needed because the information taken from the literature on the NPP of plantations comprised, in general, data from around 1995. Following the rules in the Kyoto Protocol - stating that sequestration credits should only be based on 'direct human activities' - the NPP data needed to be adjusted. This is because these data include a growth stimulus caused by, among other factors, increasing $\mathrm{CO}_{2}$ concentrations (which form 'indirect human activities'). The CF95 value for each plantation type (Table 5) has been derived by applying the IMAGE-2 $\mathrm{C}$-cycle model in order to define the growth stimulants from $\mathrm{CO}_{2}$ and climate since 1970 . Note that we correct the sequestration potential up to 2100 in a similar way:

$$
A G F_{t s}=\frac{F N P P_{C P, t s}}{N P P I_{l c t}(t s) \cdot C F 95_{t s}}
$$

where

FNPP $_{\mathrm{CP}, \mathrm{ts}}$ Average NPP of full grown plantations (Mg C ha-1 yr-1) around 1995 (Eq. 3)

$\mathrm{NPPI}_{\text {lct(ts) }}$ Average NPP of all grid cells in 1970 covered by land-cover type lct(ts) (Mg C ha-1 yr-1) [19]

CF95 $5_{\text {ts }}$ Correction Factor for climate-induced growth stimulants for 1970-1995 (-).

$F N P P_{C P}$ can be derived from especially literature on plantations yields $([27,28,34,50,51]$ and Table 6$)$. This information is subsequently used in Equation 3 (see also [19])

$$
\begin{aligned}
& F=\left(\frac{A S}{L S}-\frac{A B}{L B}\right)+\left(0.5-\frac{2 A S}{L S}-\frac{2 A B}{L B}\right) \\
& F N P P_{C P}=\frac{\frac{Y L D \cdot W D \cdot C F \cdot L R L}{H I}}{F \cdot\left(L R L-\frac{\operatorname{Recov}}{2}\right)}
\end{aligned}
$$

where

$$
\text { AS Allocation Fraction of Stems }(=0.3)
$$

LS Lifetime of stems, based on the underlying land-cover types lct(ts) (yr)

AB Allocation Fraction of Branches $(=0.2)$
LB Lifetime of branches, based on the underlying landcover types lct(ts) (yr)

YLD Yield of a plantation averaged over a rotation $\left(\mathrm{m}^{3}\right.$ Fresh Volume ha-1 $\mathrm{yr}^{-1}$ ); (Table 7)

WD Wood density (Mg dry matter. $\mathrm{m}^{-3}$ fresh volume; see Table 1)

HI Average harvest index or the fraction of above-ground biomass used (Table 1) of which the remainder decomposes to humus (-)

CF Average carbon factor or carbon content $\left(\mathrm{Mg} \mathrm{C} \mathrm{m}^{-3} \mathrm{dry}\right.$ matter)

Recov Recovery time or the average time for a carbon plantation to reach maturity in terms of NPP (yr) (Table 6).

The last part in determining the physical potential (step 1) is to estimate the net $\mathrm{C}$ sequestration (CSeq) potential of the best growing species in a grid cell. This calculation is based on the concept of SPP (Surplus Potential Productivity), as introduced by Onigkeit et al. [52]. The basic philosophy is to account only for the net $\mathrm{C}$ uptake of a plantation (Equation 4). This is calculated by using emissions associated with the conversion from natural land cover into a plantation and comparing the NEP flux of a plantation with the NEP flux of the natural vegetation that would otherwise grow in the area. As such, CSeq determines the additionality compared to the situation of having no plantations. Note that a negative value of CSeq corresponds to a biospheric uptake of carbon from the atmosphere. In our application, the NEP fluxes are simulated by the terrestrial C cycle model of IMAGE 2, taking into account NPP and soil respiration (see below).

$$
C S e q=b \cdot E+\sum_{t=t_{0}}^{t=2100}\left[N E P(t)-N E P_{C P}(t)\right]
$$

where

CSeq Net carbon sequestration in a grid cell in the period t0 through $2100\left(\mathrm{Mg} \mathrm{C} \mathrm{ha}^{-1}\right)$

t Year (between 2000 and 2100)

to Starting year of carbon plantations in a grid cell

$\mathrm{NEP}_{\mathrm{CP}}(\mathrm{t})$ Net Ecosystem Productivity of best growing tree species in a grid cell $\left(\mathrm{Mg} \mathrm{C} \mathrm{ha-1}^{-1} \mathrm{yr}^{-1}\right)$

NEP(t) NEP of the original vegetation according to the baseline scenario $\left(\mathrm{Mg} \mathrm{C} \mathrm{ha-1}^{-1} \mathrm{yr}^{-1}\right)$ 
Table 7: Comparison of plantation growth rates around the world $\left(\mathrm{m}^{3} \mathrm{ha}^{-1} \mathrm{yr}^{-1}\right)$.

\begin{tabular}{|c|c|c|c|c|c|c|c|c|c|}
\hline Species & This study & {$[27]$} & [28] & {$[34]$} & [48] & {$[61]$} & {$[7 I]$} & {$[77]$} & {$[78]$} \\
\hline E. camaldulensis & 18 & $6-38$ & $15-30$ & $15-30$ & & & & & $4-34$ \\
\hline E. grandis & 28 & & $15-50$ & $15-50$ & $\begin{array}{l}30-35 \text { (tropics) } \\
16-30 \text { (rest of world) }\end{array}$ & 25 & & & $35-50$ \\
\hline P. radiate & 16 & 26 & $12-35$ & $12-35$ & $20-22$ & & $11-25$ & $18-30$ & $8-23$ \\
\hline Poplar spp. & 19 & $9-30$ & & & $12-20$ & & $9-19$ & & $8-40$ \\
\hline Picea abies & 13 & $5-21$ & & & & $5-8$ & $10-15$ & & $4-12$ \\
\hline Larix kaempferi & 8 & $5-14$ & & & & & & & $4-12$ \\
\hline
\end{tabular}

E C content of natural vegetation before the conversion into a carbon plantation $(\mathrm{Mg} \mathrm{C} \mathrm{ha-1)}$

b Burn factor of the initial harvest [either 0 or 1] (-)

The variables $E$ and $\mathrm{b}$ account for carbon emissions related to the establishment of a carbon plantation. For plantations established on abandoned agricultural land, grassland or forest land just being logged, there is no clearing needed and ' $b$ ' is close to zero. When, however, an existing natural forest or woodland is converted into a carbon plantation, the original vegetation is assumed to be burnt entirely (i.e. $b=1$ ), resulting in instantaneous emissions of carbon into the atmosphere. These emissions must first be compensated before a plantation is effective in mitigating the $\mathrm{CO}_{2}$ build-up in the atmosphere.

Since management can have a considerable effect on the carbon uptake potential of plantations [53,54], we included two possible harvest regimes. Either plantations are harvested at regular intervals or no harvest takes place at all. In the latter case, a plantation will grow to a stable level of carbon storage and a low additional C sequestration further in time in the soil. In the former case, a plantation is harvested at the moment of maximum $\mathrm{C}$ sequestration, (i.e. the NEP of a plantation averaged over the stand age starts to decrease), followed by re-growth. In our assessment the harvested wood from stems and branches is used to fulfill the wood demand. Leaves, roots and the non-harvested stems and branches enter the litter and humus carbon pools in the soil. The approach of displacing wood demand amounts to a displacement factor of 1 (assuming no leakage, i.e. no change in the wood sector).

Figure 5 illustrates step 1 , showing the $\mathrm{C}$ dynamics of a Pinus radiata plantation on either abandoned agriculture or replacing a natural forest. In the case of establishing this plantation on abandoned agricultural land, the NPP of both the plantation and the natural forest - that would otherwise grow in the area - increases from zero up to the maximum value within the predefined recovery period. If responses to changing atmospheric $\mathrm{CO}_{2}$ levels and cli- mate are excluded, the NPP values will remain constant at the maximum value. The soil respiration of both the plantation and natural forest first decline because the carbon input from young trees is limited, whereas the decomposition rate starts at the much higher equilibrium level with respect to the previous (in this case agricultural) vegetation. After a period of decline, the respiration flux increases, since the soil carbon pools are filled up again. The respiration flux increases until it exceeds NPP. If the net carbon uptake of the carbon plantation $[\operatorname{NEPCP}(t)]$ is larger than the net uptake of the natural forest $[N E P(t)]$ (i.e. more negative), the plantation is effective in slowing down the build-up of atmospheric $\mathrm{CO}_{2}$. This is illustrated by negative values of CSeq. Since it is unknown in advance when a certain potential is actually used in a mitigation effort, we averaged the carbon sequestration over a predefined period of time expressed as $C S e q_{\text {sup }}$. As such, the CSe$q_{\text {sup }}$ over the time interval $\left[t_{s^{\prime}} t_{t}\right]$ is an approximation of the average net carbon sequestration over the time interval $\left[t_{0}, t_{e}\right]$.

In the case of the establishment of a $\mathrm{C}$ plantation on slash and burnt natural ecosystems (Figure 5), large quantities of carbon are emitted instantaneously (i.e. $E$ will be large). Afterwards, $C S e q(t)$ in year $t$ equals $N E P_{C P}(t)$, assuming no $\mathrm{CO}_{2}$ fertilization and other climate feedbacks (as such, the NEP of the natural vegetation is about 0 ). However, the year that a plantation starts to actually sequester carbon is postponed because the initial emissions have to be compensated (about 23 years for the example in Figure 5).

\section{Step 2: The social sequestration potential}

The social potential of the afforestation activities is estimated in two stages. Firstly, we establish plantations around the world using certain restrictions based on social acceptance. This is accomplished by using a particular definition of social importance: Considering only those areas that are neither needed for food and wood supply nor are covered by natural ecosystems (because of their importance for nature conservation). Establishing plantations on abandoned agricultural land is the only possibility. This leads to uptake potentials per grid cell (geographical explicit). Secondly, supply curves have been constructed 

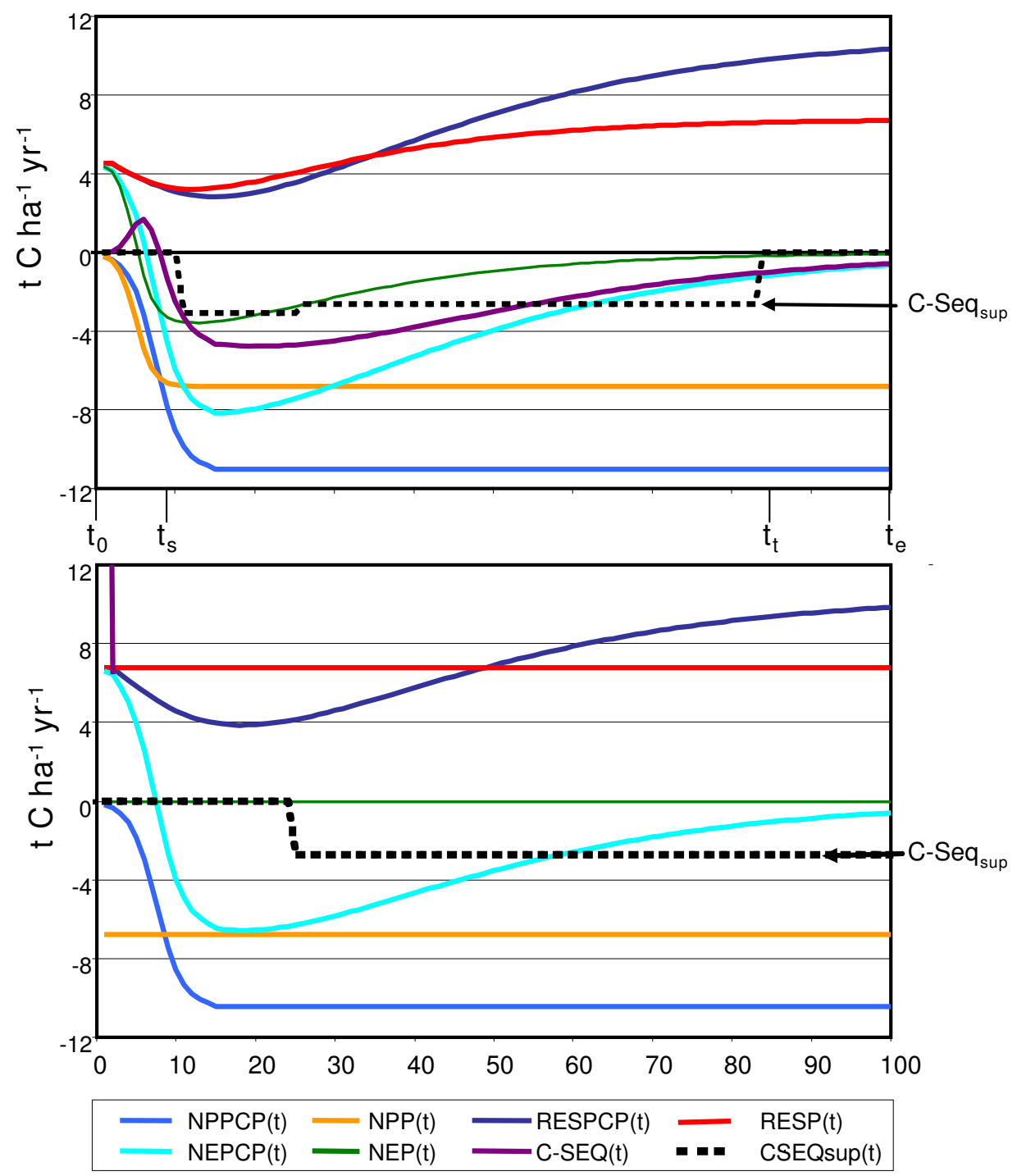

Figure 5

Illustrative growth curves of a Pinus radiata plantation: top - permanent plantation on abandoned agricultural land; bottom - permanent plantation on former forest area. Note that negative numbers represent a $C$ uptake. Furthermore, the curves assume neither $\mathrm{CO}_{2}$ fertilization nor climate feedbacks.

for each IMAGE-2 region, summing-up the gridded sequestration potentials for all grid cells within that region where the average carbon sequestration, corrected for climate change and $\mathrm{CO}_{2}$ fertilization effects, is positive in a year ' $z$ ' (Figure 5, [19]). Since it is unknown when a certain potential is actually used in a mitigation effort, and to allow for comparison with other greenhouse gas mitigation options, the carbon sequestration is averaged over a predefined period of time $\left(\mathrm{CSeq}_{\text {sup }}(\mathrm{t})\right)$. Thus each point in a supply curve represents the regional sum of the average annual carbon sequestration potential of a grid cell assigned to a time interval $\left[t_{s^{\prime}}, t_{t}\right]$, starting with the most productive grid cells (i.e. cells with highest sequestration rate per hectare), ending with ineffective grid cells.

Step 3: The economic sequestration potential

The social $\mathrm{C}$ sequestration potential is used to determine the economic potential by linking it to costs (see [19] for details). This results in Marginal Abatement Curves (MACs) or cost-supply curves dependent on geographicalexplicit environmental circumstances and possible future changes in land use. In general, the most important cost factor in producing or conserving carbon sinks is land [55]. In addition, we also consider establishment costs. 
Other types of costs are excluded because they are either low (e.g. maintenance costs), compensated by revenues from timber, or difficult to quantify [56]. Land costs are based on GTAP data [57] for land values of agricultural land around the world. Establishment costs, set at 435 US\$ (1995) per ha, are uniform in time and space. This assumption is supported by the survey of Sathaye et al. [15]. The value of 435 US\$ (1995) per ha is based on analyzing variations between the regions and the ranges within the regions.

\section{The IMAGE 2 model}

The methodology presented has been implemented in IMAGE 2 (Integrated Model to Assess the Global Environment $[18,58,59])$. This is a multi-disciplinary, integrated assessment model, designed to explore causes and effects of global environmental change. IMAGE 2 integrates different land-use demands like food, fodder, biofuels and C sequestration. IMAGE 2 is global in application and integrates regional socio-economic (i.e. eighteen regions) and geographically explicit grid dimensions (i.e. $0.5^{0}$ longitude by $0.5^{\circ}$ latitude). Each grid cell is characterized by its climate, soil and land cover (natural ecosystems or agriculture). Because of the dynamic land use, the geographic explicit modeling and the global perspective, IMAGE 2 is very suitable for the presented methodology.

IMAGE 2 consists of various sub-models (Figure 6). Drivers of the model are regional trends in wealth, demography and technology for the period 1970 to 2100 . These trends determine, for example, the demand for land resources. Changes in production of or demand for landrelated products (i.e. food, fodder, biofuel, timber and C sequestration) drive land-use changes, leading to land-use emissions of various greenhouse gases into the atmosphere. The IMAGE 2 atmospheric and ocean sub-model computes changes in atmospheric composition (e.g. $\mathrm{CO}_{2}$ and $\mathrm{CH}_{4}$ ) and, subsequently, the climate by using the land-use and energy-related emissions and by taking oceanic and terrestrial $\mathrm{CO}_{2}$ uptake and atmospheric chemistry into account. The climatic changes alter the distribution and productivity of ecosystems and agriculture, with both, in turn, affecting the terrestrial C dynamics.

Carbon plantations have been added as a separate landcover class into the land-cover sub-model of IMAGE 2, whereas their carbon pools and fluxes are computed by the terrestrial C cycle sub-model $[19,49,60]$. The driving force of the $\mathrm{C}$ cycle sub-model is Net Primary Productivity (NPP), which is the photosynthetically fixed $\mathrm{C}$ in plants minus $\mathrm{C}$ losses due to plant respiration. NPP in IMAGE 2 is a function of atmospheric $\mathrm{CO}_{2}$ concentration, climate, soil nutrient and moisture status, biome type and the successional stage of a biome. NPP determines the Net Eco- system Productivity (NEP) in an area, together with the heterotrophic soil respiration. NEP represents the net $\mathrm{C}$ flux between the atmosphere and terrestrial ecosystems. Soil respiration depends on the $\mathrm{C}$ stocks in the different soil compartments (i.e. litter, humus and charcoal), their turnover rates and environmental conditions (i.e. soil water availability and temperature). All fluxes are calculated on a monthly basis, while the carbon pools are updated annually.

\section{Model application and experimental design}

The IMAGE 2 model, along with the methodology presented here, has been applied to a number of experiments to show different sequestration potentials of $\mathrm{C}$ plantations up to 2100 under different baseline scenarios and management options. The experiments form variants to the implementation of the IPCC SRES A1b and B2 baseline scenarios $[20,59]$. The two baseline scenarios differ considerably in socio-economic and population developments (Table 8). In the $\mathrm{B} 2$ scenario, the demands up to 2050 for goods (e.g. food, timber and biofuels) are lower than in A1b baseline. But between 2050 and 2100, the demands remain high in $\mathrm{B} 2$, and drop in the A1b scenario. Combined with lower yield increases in the $\mathrm{B} 2$ world due to lower economic development and a fragmented world (e.g. leading to less technology exchange), less agricultural land is projected as being available for $\mathrm{C}$ plantations in the $\mathrm{B} 2$ scenario than in the A1b scenario. The consequences for the atmospheric $\mathrm{CO}_{2}$ concentration and global climate in the two scenarios are given in Table 8. Regionally, large temperature changes (up to $6^{\circ} \mathrm{C}$ ) are simulated for the high latitudes, the Amazonian region, southern Africa and India.

In the first set of experiments, the physical sequestration potential is estimated by establishing plantations wherever the carbon sequestration is higher than in the baseline (Table 9), with the exception of areas used for agriculture. The variants deal with permanent plantations in the A1b scenario (Exp.1) and frequently harvested plantations in the A1b (Exp. 2) and B2 (Exp.3) baseline scenarios. In the second set of experiments we assess the social sequestration potential by taking into account such barriers as no interference with the food supply and nature concerns. We implemented these criteria by establishing plantations on abandoned agricultural land only. Reforestation of harvested timberland is, for example, excluded, but could easily be incorporated in the methodology presented. Just as for the first set of experiments, we distinguish different types of management (Experiments 4 and 5) and baseline scenarios (Experiments. 4 and 6). In this set of experiments we assume that the plantations will actually be established, allowing for an evaluation of the possible role of carbon plantations in mitigating the build-up of $\mathrm{CO}_{2}$ in the atmosphere (Table 4). 


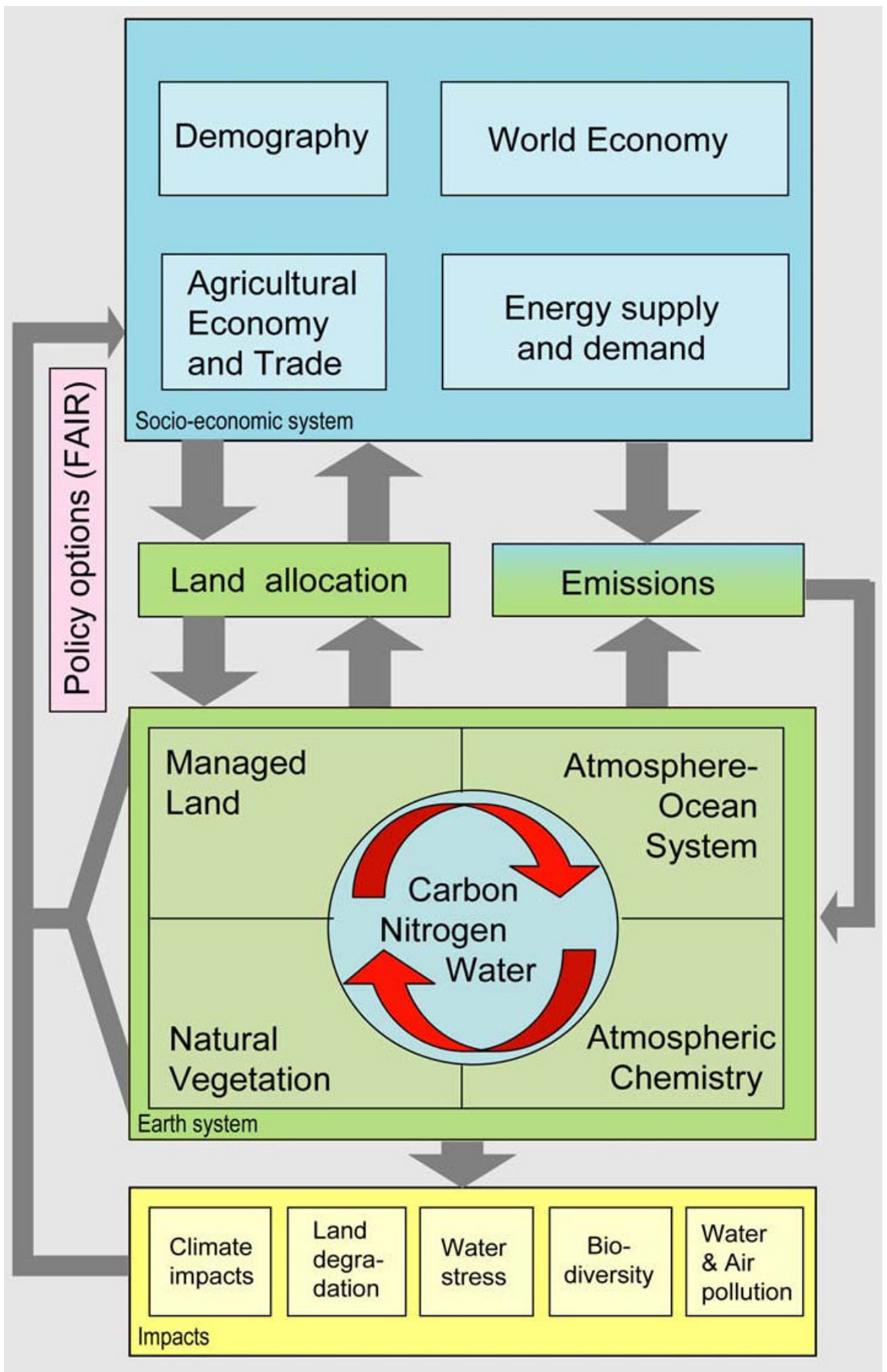

Figure 6

Structure of IMAGE 2. 
Table 8: Main global characteristics of the IPCC AIb and B2 baseline scenarios (derived from The IMAGE Team [59]).

\begin{tabular}{|c|c|c|c|}
\hline Variable & Year & Alb & B2 \\
\hline Population & 2020 & 7.6 & 7.7 \\
\hline (109 people) & 2050 & 8.7 & 9.4 \\
\hline (in 2000: 6.1) & 2100 & 7.1 & 10.4 \\
\hline GDP/capita & 2020 & 8.8 & 7.6 \\
\hline$\left(10^{3}\right.$ US $\left.\$ y^{-1}\right)$ & 2050 & 24.2 & 13.7 \\
\hline (in 2000: 5.3) & 2100 & 86.2 & 27.7 \\
\hline Extent arable land & 2020 & 51.7 & 53.1 \\
\hline$\left(\mathrm{Mkm}^{2}\right)$ & 2050 & 53.1 & 53.6 \\
\hline (in 2000: 48.5) & 2100 & 48.4 & 51.0 \\
\hline Atmospheric $\mathrm{CO}_{2}$ & 2020 & 426 & 421 \\
\hline Concentration (ppm) & 2050 & 561 & 506 \\
\hline (in 2000: 375) & 2100 & 753 & 606 \\
\hline \multirow[t]{3}{*}{ Air temperature change $\left({ }^{\circ} \mathrm{C}\right)$ (in 2000: 0.6 ) } & 2020 & 1.0 & 1.0 \\
\hline & 2050 & 2.0 & 1.9 \\
\hline & 2100 & 3.4 & 2.9 \\
\hline
\end{tabular}

\section{List of abbreviations}

CO2: Carbon dioxide; Ha: Hectare; NPP: Net Primary Production; NEP: Net Ecosystem Productivity.

\section{Competing interests}

The authors declare that they have no competing interests.

\section{Authors' contributions}

The methodology and its applications were designed by JvM, who also prepared this manuscript. B.S. co-designed the methodology, implemented it in IMAGE 2 and contributed to the paper. BE contributed to the different stages of the methodology and earlier versions of this paper. RS and RL contributed to all stages of the paper. All authors read and approved the final manuscript.

Table 9: Overview of simulation experiments for the IPCC AIb or B2 baseline scenarios

\begin{tabular}{llll}
\hline & Plantation management & IPCC AIb & IPCC B2 \\
\hline Physical potential & Permanent & Experiment I & Experiment 3 \\
& Frequent harvest & Experiment. 2 & Experiment 4 \\
Social potential & Permanent & Experiment 5 & Experiment 6 \\
& & &
\end{tabular}




\section{Acknowledgements}

The research was made possible by internal funding from MNP and WUR

We would like to thank Michiel Schaeffer for his contribution and discussion to the development the plantation scenarios based on the SRES scenarios. We are also indebted to Ruth de Wijs for carefully checking and improving the English.

\section{References}

I. Schellnhuber HJ, Cramer W, Nakicenovic N, Wigley T, Yohe G, Eds: Avoiding Dangerous Climate Change. Cambridge, UK: Cambridge University Press; 2006:406.

2. Hegerl GC, Zwiers FW, Braconnot P, Gillett NP, Luo Y, Marengo J, Nicholls N, Penner JE, Stott PA: Understanding and Attributing Climate Change. In Climate Change 2007: The Physical Science Basis. Working Group I Contribution to the Fourth Assessment Report of the Intergovernmental Panell on Climate Change (IPCC) Volume Chapter 9. Edited by: Solomon S, Qin D, Manning M, Chen Z, Marquis M, Averyt K, Tignor MMB, Miller HL. Cambridge University Press, Cambridge, UK; 2007:663-746.

3. UNFCCC: The United Framework Convention on Climate Change. UN 1993.

4. Morita T, Robinson J, Adegbulugbe A, Alcamo J, Herbert D, La Rovere EL, Nakicenovic N, Pitcher H, Raskin P, Riahi K, et al.: Greenhouse Gas Emission Mitigation Scenarios and Implications. In Climate change 200 I: Mitigation, Contribution of working group III to the Third Assessment Report of the Intergovernmental Panell on Climate Change (IPCC) Volume Chapter 3. Edited by: Metz B, Davidson O, Swart R, Pan J. Cambridge University Press, London, New York: 2001:115-166.

5. Leemans R, Eickhout B: Another reason for concern: regional and global impacts on ecosystems for different levels of climate change. Global Environmental Change 2004, 14:219-228.

6. Noble IR, Scholes RJ: Sinks and the Kyoto Protocol. Climate Policy 2000, I:5-25.

7. Bruinsma JE, Ed: Agriculture: Towards 2015/2030. A FAO Perspective. London: Earthscan; 2003:432

8. Hoogwijk M, Faaij A, Eickhout B, De Vries B, Turkenburg W: Potential of biomass energy out to 2100 for four IPCC SRES landuse scenarios. Biomass \& Bioenergy 2005, 29:225-257.

9. Reid WV, Mooney HA, Cropper A, Capistrano D, Carpenter SR, Chopra K, Dasgupta P, Dietz T, Duraiappah AK, Hassan R, Kasperson R, Leemans R, May RM, McMichael AJ, Pingali P, Samper C, Scholes R, Watson RT, Zakri AH, Shidong Z, Ash NJ, Bennett E, Kumar P, Lee M], Raudsepp-Hearne C, Simons H, Thonell J, Zurek MB: Millennium Ecosystem Assessment Synthesis Report. Island Press, Washington DC; 2005:219.

10. Watson RT, Noble IR, Bolin B, Ravindranth NH, Verado D, Dokken DJ, Eds: IPCC Special report on Land Use, Land-Use Change, and Forestry. Cambridge: Cambridge University Press; 2000:377.

II. Schneider U, McCarl B: Economic Potential of Biomass Based Fuels for Greenhouse Gas Emission Mitigation. Environmental \& Resource Economics 2003, 24(4):29I-312.

12. Sohngen B, Mendesohn R: An Optimal Control Model of Forest Carbon Sequestration. American Journal of Agricultural Economics 2003, 85:448-457.

13. Hamilton C, Vellen L: Land-use changes in Australia and the Kyoto protocol. Environmental, Science and Policy 1999, 2:135-I44.

14. Nabuurs G], Dolman A], Verkaik E, Kuikman P], van Diepen CA Whitmore AP, Daamen WP, Oenema O, Kabat P, Mohren GMJ: Article 3.3 and 3.4 of the Kyoto Protocol: consequences for industrialised countries' commitment, the monitoring needs, and possible side effects. Environmental Science and Policy 2000, 3: $123-134$

15. Sathaye JA, Markundi W, Andrasko K, Boer R, Ravindranath $\mathrm{NH}$, Sudha $P$, Rao S, Lasco R, Pulhin F, Masera O, et al.: Carbon mitigation potential and costs of forestry options in Brazil, China, India, Indonesia, Mexico, the Philippines and Tanzania. Mitigation and Adaptation Strategies for Global Change 200I, 6: I85-2II.

16. Sathaye JA, Markundi W, Dale L, Chan P, Andrasko K: GHG Mitigation Potential, Costs and Benefits in Global Forests: A Dynamic Partial Equilibrium Approach. Multi-Greenhouse
Gas Mitigation and Climate Policy Special Issue \#3. Energy Journal 2006.

17. Sohngen B, Sedjo RJ: Carbon sequestration costs in global forests. Energy Journal 2006.

18. MNP: Integrated modelling of global environmental change. An overview of IMAGE 2.4. Bilthoven, the Netherlands: Netherlands Environmental Assessment Agency (MNP); 2006:228.

19. Strengers B, van Minnen JG, Eickhout B: The costs and uncertainties in establishing $C$ plantations in order to mitigate climate change. Climatic Change 2008 in press.

20. Nakicenovic N, Alcamo J, Davis G, de Vries B, Fenhann J, Gaffin S, Gregory K, Grübler A, Jung TY, Kram T, Emilio la Rovere E, Michaelis L, Mori S, Morita T, Pepper W, Pitcher H, Price L, Riahi K, Roehrl A, Rogner H-H, Sankovski A, Schlesinger ME, Shukla PR, Smith S, Swart RJ, van Rooyen S, Victor N, Dadi Z, Eds: IPCC Special Report on Emissions Scenarios. Cambridge: Cambridge University Press London, New York; 2000:599.

2I. Masera OR, Garza-Caligaris JF, Kanninen M, Karjalainen T, Liski J, Nabuurs G], Pussinen A, Jong BHJd, Mohren GMJ: Modeling carbon sequestration in afforestation, agroforestry and forest management projects: the CO2FIX V.2 approach. Ecological Modelling 2003, 164:177-199.

22. Cannell MGR: Carbon sequestration and biomass energy offset: Theoretical, potential and achievable capacities globally, in Europe and the UK. Biomass and Bioenergy 2003, 24:97-116.

23. Silver $\mathrm{WL}$, Ostertag $\mathrm{R}$, Lugo $\mathrm{AE}$ : The potential for carbon sequestration though reforestation of abandoned tropical agricultural and pasture lands. Restoration Ecololgy 2000, 8:394-407.

24. Liski J, Karjalainen T, Pussinen A, Nabuurs GJ, Kauppi P: Trees as carbon sinks and sources in the European Union. Environmental Science and Policy 2000, 3:91-97.

25. Marland G, Schlamadinger B: The Kyoto protocol could make a difference for the optimal forest based $\mathrm{CO} 2$ mitigation strategy: Some results for GORCAM. Environmental Science and Policy 1999, 2:111-124.

26. Kirschbaum MF: Can trees buy time? An assessment of the role of vegetation sinks as part of the global carbon cycle. Climatic Change 2003, 58:47-7I.

27. Brown C: The global outlook for future wood supply from forest plantations. Food and Agriculture Organization of the United Nations (FAO), Report GFPOS/WP/03, Rome; 2000:141.

28. FAO: Global forest resources assessment 2000. Food and Agriculture Organization of the United Nations (FAO), Main Report 140 2001:479.

29. Houghton RA: Revised estimates of the annual flux of carbon to the atmosphere from changes in land use and land management 1950-2000. Tellus B 2003, 55:378-390.

30. Ravindranath N, Somashekhar B: Potential and Economics of Forestry Options for Carbon Sequestration in India. Biomass and Bioenergy 1995, 8:323-336.

3I. Sathaye JA, Andrasko K, Markundi W, Lebre La Rovere E, Ravindranath NH, Melli A, Rangaschari A, Imaz M, Gay C, Friedmann R, et al:: Concerns about climate change mitigation projects: Summary of findings from case studies in Brazil, India, Mexico and South Africa. Environmental Science and Policy 1999, 2:187-198.

32. Metz B, Berk M, Kok M, Van Minnen JG, De Moor A, Faber A: How can the European Union contribute to a CoP-6 agreement? An overview for policy makers. International Environmental Agreement: Politics, Law and Economics 200 I, I:167-185.

33. Schlamadinger B, Marland G: The Kyoto Protocol: Provision and unresolved issues relevant to land-use change and forestry. Environmental Science and Policy 1998, I:3 I3-327.

34. IPCC: Good Practice Guidance for Land Use, Land-Use Change and Forestry. Special report of the Intergovernmental Panell on Climate Change (IPCC), Cambridge University Press, Cambridge, UK:599.

35. Stinson G, Freenman B: Potential for carbon sequestration in Canadian forests and agroecosystems. Mitigation and Adaptation Strategies for Global Change 200I, 6: I-23.

36. Deckmyn G, Muys B, Garcia Quijano J, Ceulemans R: Carbon sequestration following afforestation of agricultural soils: comparing oak/beech forest to short-rotation poplar coppice combining a process and a carbon accounting model. Global Change Biology 2004, 10:|482-|49|. 
37. Fearnside PM: The potential of Brazil forest sector for mitigating global warming under the Kyoto Protocol. Mitigation and Adaptation Strategies for Global Change 2001, 6:355-372.

38. Betts RA: Offset of the potential carbon sink from boreal forestation by decreases in surface albedo. Nature 2000, 408:187-190.

39. Marland G, Pielke RA, Apps M, Avissar R, Betts RA, Davis KJ, Frumhoff PC, Jackson ST, Joyce LA, Kauppi P, et al: The climatic impacts of land surface change and carbon management, and the implications for climate-change mitigation policy. Climate Policy 2003, 3: 149-157.

40. Schaeffer M, Eickhout B, Hoogwijk M, Strengers B, Van Vuuren D, Leemans $\mathrm{R}$, Opsteegh $\mathrm{T}: \mathbf{C O}_{2}$ and albedo climate impacts of extratropical carbon and biomass plantations. Global Biogeochemical Cycles 2006, 20:GB2020. doi 2010-1029/2005GB00258I

4I. Jackson RB, Jobbagy EG, Avissar R, Roy SB, Barrett DJ, Cook CW, Farley KA, Maitre DCI, McCarl BA, Murray BC: Trading Water for Carbon with Biological Carbon Sequestration. Science 2005 310:1944-1947.

42. Schlesinger WH: Carbon sequestration in soils: Some cautions amidst optimism. Agriculture, Ecosystems and Environment 2000 82: $127-127$

43. Hungate BA, Dukes $\mathrm{S}$, Shaw MR, Luo $Y$, Field CB: Nitrogen and Climate Change. Science 2003, 302(5650): $1512-1513$.

44. Keppler F, Hamilton JTG, Braß M, Röckmann T: Methane emissions from terrestrial plants under aerobic conditions. Nature 2006, 439:|87-|9|.

45. Kirschbaum MUF, Bruhn D, Etheridge DM, Evans JR, Farquhar GD, Gifford RM, Pau KI, Winters Al: A comment on the quantitative significance of aerobic methane release by plants. Functional Plant Biology 2006, 33:52I-530.

46. Sathaye J, Bouille D, Biswas D, Crabbe P, Geng L, Hall D, Imura $H$ Jaffe A, Michaelis L, Peszko G, et al.: Barriers, Opportunities, and Market Potential of Technologies and Practices. In Climate change 200I: Mitigation, Contribution of working group III to the Third Assessment Report of the Intergovernmental Panell on Climate Change (IPCC) Edited by: Metz B, Davidson O, Swart R, Pan J. Cambridge University Press, London, New York: IPCC; 200 I:35I-758.

47. Van Vuuren D, Den Elzen M, Lucas $P$, Eickhout $B$, Strengers $B$, Van Ruijven B, Wonink S, Van den Houdt R, Berk M, Oostenrijk R: Stabilising greenhouse gas concentrations. Assessment of different strategies and costs using an integrated assessment framework. Climatic Change 2007, 8 I : I I9-I59.

48. Leemans R, Eickhout BJ, Strengers B, Bouwman AF, Schaeffer M: The consequences for the terrestrial carbon cycle of uncertainties in land use, climate and vegetation responses in the IPCC SRES scenarios. Science in China 2002, 43:I-I5.

49. Van Minnen JG, Strengers B, Eickhout B, Klein Goldewijk K: Simulating carbon exchange between the terrestrial biopshere and atmosphere. In Integrated modelling of global environmental change An overview of IMAGE 24 Edited by: Bouwman AF, Kram T, Klein Goldewijk K. Bilthoven, the Netherlands; 2006: I I3-130.

50. Del Lungo A: Planted forest database: Analysis of annual planting trends and silvicultural parameters for commonly planted species. Food and Agriculture Organization of the United Nations (FAO), Working Paper FP/26, Rome 2003:60.

5I. FAO: Assessing carbon stocks and modelling win-win scenarios of carbon sequestration through land-use changes. FAO, Rome 2004:68.

52. Onigkeit J, Sonntag M, Alcamo J: Carbon Plantations in the IMAGE model - Model: Description and scenarios. Center for Environmental Systems Research, Uni. Kassel, Kassel, Germany 2000:4l.

53. Karjalainen T, Pussinen A, Liski J, Nabuurs GJ, Eggers T, Lapvetelainen $T$, Kaipainen $T$ : Scenario analysis of the impacts of forest management and climate change on European forest sector carbon budget. Forest Policy and Economics 2003, 5:14I-155.

54. Phat NK, Knorr W, Kim S: Appropriate measures for conservation of terrestrial carbon stocks - Analysis of trends of forest management in Southeast Asia. Forest Ecology and Management 2004, 191:283-299.

55. Richards KR, Stokes C: $\mathbf{A}$ review of forest carbon sequestration cost studies: A dozen years of research. Climatic Change 2004, 63: $1-48$.

56. Benítez PC, McCallum I, Obersteiner M, Yamagata Y: Global potential for carbon sequestration: Geographical distribution, country risk and policy implications. Ecological Economics 2006, 60:572-583

57. GTAP: The GTAP 6 Data package. Purdue University, USA; 2004.

58. Alcamo J, Kreileman GJJ, Krol M, Leemans R, Bollen J, Van Minnen JG, Schaefer F, Toet S, De Vries B: Global modelling of environmental change: An overview of IMAGE 2.I. In Global change scenarios of the 2 I st century Results from the IMAGE 2 I model Edited by: Alcamo J, Leemans R, Kreileman GJJ. London: Pergamon Press/Elsevier Science; 1998:3-94.

59. IMAGE team: The IMAGE 2.2 implementation of the SRES scenarios: A comprehensive analysis of emissions, climate change and impacts in the 2 Ist century. National Institute of Public Health and the Environment, RIVM CD-ROM Publication, 48I5080I8, Bilthoven; 200I.

60. Klein Goldewijk K, Van Minnen JG, Kreileman GJJ, Vloedbeld M, Leemans R: Simulation of the carbon flux between the terrestrial environment and the atmosphere. Water, Air and Soil Pollution 1994, 76:199-230.

6I. Nilsson S, Schopfhauser W: The carbon-sequestration potential of a global afforestation program. Climatic Change 1995, 30:267-293

62. Vrolijk C, Grubb M, Metz B, Haites E: Quantifying Kyoto Workshop. A summary. 2000 [http://www.riia.org/research]. Royal Institute of International Affairs, London

63. Lal R: Global Potential of soil carbon sequestration to mitigate the greenhouse effect. Critical Reviews in Plant Sciences 2003, 22: $15 \mid-184$

64. EEA: Greenhouse gas emission projections and costs 1990-2030. European Environmental Agency, Technical paper 2004/I Copenhagen, Denmark; 2004:82.

65. Smith P, Andren O, Brussaard L, Dangerfield M, Ekschmitt K, Lavelle $P$, Tate K: Soil biota and global change at the ecosystem level: describing soil biota in mathematical models. Global Change Biology 1998, 4:773-784.

66. NFCCC: Document on the Implementation of the Buenos Aires Plan for Action. UNFCCC secretariat, UNFCCC/CP/ 20000/L.7, Bonn, Germany; 200 I.

67. Krankina ON, Harmon ME, Cohen WB, Doug R, Oetter, Zyrina O, Duane MV: Carbon stores, sinks, and sources in forests of Northwestern Russia: Can we reconcile forest inventories with remote sensing results? Climatic Change 2004, 67:257-272.

68. Chen W, Chen JM, Price DT, Cihlar J, Liu J: Carbon offset potentials of four alternative forest management strategies in Canada: a simulation study. Mitigation and Adaptation Strategies for Global Change 2000, 5:143-169.

69. Liski J, Korotkov A, Prins CFL, Karjalainen T, Victor DG, Kauppi PE: Increased carbon sink in temperature and boreal forests. Climatic Change 2003, 61:89-99.

70. Cramer W, Solomon AM: Climatic classification and future global redistribution of agricultural land. Climate Research 1993 , 3:97-110

7I. Nabuurs G], Mohren GMJ: Carbon fixation through forestry activities. IBN-DLO, Wageningen, the Netherlands, 93/4; 1993.

72. Cannell MGR: World Forest Biomass and Primary Production Data. New York: Academic Press; New York; 1982:39I.

73. Schober R: Ertragstafeln wichtiger Baumarten. J.D. Sauerlander Verlag, Frankfurt a.M; I 975: 154.

74. Ilic J, Boland D, McDonald M, Downes G, Blakemore P: Woody Density Phase I - State of Knowledge. Australian Greenhouse Office, Tech. Report I8 2000:234.

75. Gracia C, Sabate S: Aboveground biomass expansion factors and biomass equations of forests in Catalonia. CREAF expert meeting on biomass expansion factors (BEF); Valencia 2002:5.

76. NRRPC: Measurement of carbon sequestration in small nonindustrial forest plantations. Northern Rivers Region Plantation Committee, Technical Report Greenhouse Gas 2004:25.

77. Van de Hoef L, Hill B: Radiata pine for farm forestry. NRE, Agriculture Notes AGI 070 2003:2

78. Tunctaner K: Sustainability of industrial forest plantations in Turkey. University of Zonguldak Kararaelmas, Faculty of Forestry, Turkey, working paper 2004:19. 